\title{
Cadmium in the North Atlantic: Implication for global cadmium-phosphorus relationship
}

Jingfeng $\mathrm{Wu}^{*}$ and Saeed Roshan

RSMAS, University of Miami, 4600 Rickenbacker Causeway, Miami, FL 33149

*Corresponding author. E-mail: jwu@ @rsmas.miami.edu, Phone: 3054214714

\begin{abstract}
Dissolved cadmium (Cd) distribution was determined in the tropical-subtropical North Atlantic along GEOTRACES GA03 Section (US GEOTRACES 2010 and 2011 cruises). A pronounced mid-depth $\mathrm{Cd}$ maximum extends from the productive tropical eastern North Atlantic where subsurface waters in the upper themocline are depleted in dissolved oxygen. At this $\mathrm{Cd}$ maximum, $\mathrm{Cd}$ depletion relative to phosphate (PO4) is observed in the $\mathrm{Cd}$ vs. $\mathrm{PO} 4$ plot, but the relative $\mathrm{Cd}$ depletion is not present in the plot of $\mathrm{Cd}: \mathrm{PO} 4$ ratio vs depth. The apparent relative $\mathrm{Cd}$ depletion at the $\mathrm{Cd}$ maximum appears to reflect a depth-dependent variation of $\mathrm{Cd}: \mathrm{PO} 4$ ratio commonly observed in the world ocean. Such depth dependent variation of Cd:PO4 ratio may result from the regeneration of $\mathrm{Cd}$ from $\mathrm{Cd}$-poor particulate organic carbon (POC) in the upper ocean and from Cd-rich POC in the deep ocean. The vertical Cd regeneration may lead to the observed difference in deep water Cd:PO4 ratio between the North Atlantic and North Pacific, if Cd to phosphorus ratio in the POC flux to the deep ocean is higher in the Pacific than in the Atlantic.
\end{abstract}




\section{Introduction}

Cadmium $(\mathrm{Cd})$ occurs in oceanic waters at picomolar to nanomolar concentrations and has a oceanic distribution similar to phosphate (PO4) (Boyle et al., 1976; Bruland, 1980). The similarity between $\mathrm{Cd}$ and PO4 in their oceanographic distribution and the correlation of the $\mathrm{Cd}: \mathrm{Ca}$ ratio of foraminiferal shells with that of seawater lead to the suggestion that the $\mathrm{Cd}: \mathrm{Ca}$ ratio recorded in foraminifera tests may be used as a proxy for past ocean PO4 (Boyle, 1981). This idea has been the basis to infer paleo deep ocean circulation from the $\mathrm{Cd}$ :Ca ratio of benthic foraminifera (Boyle, 1988) and the paleo PO4 utilization in the surface water of the Southern Ocean from Cd:Ca ratio of planktonic foraminifera (Elderfield and Rickaby, 2000). A mechanistic understanding of the relationship between $\mathrm{Cd}$ and PO4 distribution in the presentday ocean is necessary if we are to appropriately interpret paleo foraminifera $\mathrm{Cd}$ :Ca data.

A compilation of global data sets shows that the plot of Cd vs PO4 has a 'kink' at 1.3 $\mu$ M PO4 (Boyle, 1988; de Baar et al., 1994; Loscher et al., 1997; Cullen, 2006), and that the $\mathrm{Cd}: \mathrm{PO} 4$ ratio increases with depth in the upper thermocline, reaches a maximum at or above the individual dissolved maxima of $\mathrm{Cd}$ and PO4 and remain constant below this depth with a higher deep water value in the North Pacific $(\sim 350 \mathrm{pM} / \mu \mathrm{M})$ than in the North Atlantic $(\sim 200 \mathrm{pM} / \mu \mathrm{M})$ (Loscher et al., 1997; Elderfield and Rickaby, 2000). The mechanism responsible for such CdPO4 relationships is not well understood. While the coincidence of $\mathrm{Cd}$ and PO4 maxima observed in the global ocean argues against the suggestion that $\mathrm{Cd}$ has a deeper regeneration cycle relative to PO4 (Boyle, 1988), the different deep water Cd:PO4 ratio between the North Atlantic and the North Pacific cannot be explained solely by the the intrusion of Antarctic 
Intermediate Water (AAIW) and Antarctic Bottom Water (AABW) (Frew, 1995; Yeats, 1998; Frew and Hunter, 1992), or by the preferential Cd extraction relative to PO4 from surface waters (Boyle, 1981, Saager and de Baar, 1993; Elderfield and Rickaby, 2000) during Zn or Fe limitation (Sunda and Huntsman, 2000; Cullen and Sherrell, 2005; Cullen, 2006; Lane et al., 2009). The measured $\mathrm{Cd}$ and PO4 in the subsurface water are composed of preformed and regenerated components. While the AAIW and AABW supply much of the preformed component, in-situ degradation of particles sinking from the euphotic zone is responsible mainly for the regenerated component observed in the deep ocean. Because the AAIW and AABW ventilate to both the Atlantic and the Pacific, the different $\mathrm{Cd}: \mathrm{PO} 4$ ratio between the North Atlantic and North Pacific is likely to result mainly from the different ratios of $\mathrm{Cd}$ and $\mathrm{PO} 4$ regenerated from sinking particles between the two oceans.

In this paper, we present the distribution of $\mathrm{Cd}$ and $\mathrm{PO} 4$ across a large gradient of surface productivity and subsurface dissolved oxygen in tropical-subtropical North Atlantic along GEOTRACES GA03 section during US GEOTRACES North Atlantic 2010 and 2011 cruises. The measured Cd profiles are compared with those simulated using a simple model that considers the effect of preformed $\mathrm{Cd}$, particle scavenging and $\mathrm{Cd}$ regeneration, to test the hypothesis that the increase of $\mathrm{Cd}: \mathrm{PO} 4$ ratio with depth in the oceanic thermocline is mainly due to $\mathrm{Cd}$ regeneration from two groups of particulate organic carbon (POC) sinking from the surface ocean: the Cd-poor non-ballast POC and the Cd-rich ballast-associated POC, and that the higher $\mathrm{Cd}: \mathrm{PO} 4$ ratio in the North Pacific than in the North Atlantic is due to higher Cd:P ratio of the ballast-POC in the North Pacific than in the North Atlantic. 


\section{Sampling and Analysis}

Seawater samples were collected along GEOTRACES GA03 section during the US North Atlantic GEOTRACES 2010 and 2011 cruises (November-December 2010 and 2011). During the 2010 cruise, the transect begins at a station near the strait of Gibraltar $\left(38.3^{\circ} \mathrm{N}, 9.7\right.$ $\left.{ }^{\circ} \mathrm{W}\right)$ and extends southward to a station $\left(17.4^{\circ} \mathrm{N}, 24.5^{\circ} \mathrm{W}\right)$ at the oxygen minimum zone of tropical eastern North Atlantic off northwest Africa. During the 2011 cruise, the transect begins at a station $\left(39.7^{\circ} \mathrm{N}, 69.8^{\circ} \mathrm{W}\right)$ in the continental slope of the western North Atlantic and extends eastward across the oligotrophic Atlantic basin to the station at $17.4^{\circ} \mathrm{N}, 24.5^{\circ} \mathrm{W}$ that was also occupied in the 2010 cruise (Figure 1a). During the 2010 cruise, eight vertical profiles of 24 samples were sampled from entire water column. During the 2011 cruise, thirteen vertical profiles of 24 to 36 samples were sampled from the entire water column. Water samples were collected with 12 L Teflon coated Go-FLO bottles mounted on US GEOTRACES carousel attached to plastic coated cable. Seawater samples were passed through $0.2 \mu \mathrm{m}$ pore Acropak cartridge filter within 12 hours after the sample collection. The sample filtrates were acidified to pH 1.7-2.0 using 2.8 ml Q-HCl ( 9 N, sub-boiling distilled in Savillex all Teflon still, Cd blank is less than $10 \mathrm{pmol} \mathrm{Cd}$ per liter of $\mathrm{HCl}$ ) per liter of seawater within 12 hours of sample filtration. The acidified samples were stored in 1-L narrow mouth low-density polyethylene bottles at room temperature for more than six months before analysis. Dissolved cadmium $(\mathrm{Cd})$ concentrations were measured in 2-ml repilicates with $\mathrm{Mg}(\mathrm{OH})_{2}$ co-precipitation isotope dilution (Wu and Boyle, 1997) using a multiple collector high resolution ICPMS (Finnigan Neptune) at the University of Miami. The detection limit $(3 \sigma)$ of the method was $\sim 5 \mathrm{pM}$ Cd with an average precision of $2 \%$ at $50 \mathrm{pM} \mathrm{Cd}$. All sample handling and analyses were carried out using trace 
metal clean procedures. PO4 was analyzed with spectrophotometry (Strickland and Parsons, 1972).

\section{Results and Discussion}

The distribution of dissolved Cd and PO4 is shown in Figure 1b and 1c and the data are listed in Table 1. Dissolved Cd and PO4 show similar patterns of surface depletion and subsurface enrichment reflecting biological uptake of $\mathrm{Cd}$ and $\mathrm{P}$ in the surface and their regeneration from sinking POC at subsurface depths. There is a pronounced $\mathrm{Cd}$ maximum extending from the eastern boundary (Figure $1 \mathrm{~b}$ ). The $\mathrm{Cd}$ maximum coincides with PO4 and AOU maximum at the thermocline depths (100-800 m) at stations USGT10-09 - USGT10-12 (Figure 1c and 1d). These stations lie in the oxygen minimum zone (OMZ) (Figure 1e) resulting from excess consumption of dissolved oxygen by microbial degradation of sinking POC due to stagnant water circulation and an enhanced surface productivity induced by upwelling (Stramma et al., 2008). The coincidence of $\mathrm{Cd}, \mathrm{PO} 4$ and $\mathrm{AOU}$ maxima and dissolved $\mathrm{O}_{2}$ minimum reflects the concurrent $\mathrm{Cd}$ and $\mathrm{PO} 4$ regeneration and dissolved oxygen consumption in the OMZ.

When Cd is plotted against PO4 (Figure 2), the Cd concentration at depths above $400 \mathrm{~m}$ in the OMZ (station USGT10-09 - USGT10-12 and USGT11-20 - USGT11-24 ) falls below the Cd-PO4 linear lines as defined by the data points determined at stations outside the OMZ (USGT10-01 - USGT10-07 and USGT11-01 - USGT11-18), suggesting a severe depletion of Cd relative to $\mathrm{PO} 4$ in the $\mathrm{OMZ}$. As vertical particle export is high in the OMZ, one may wonder if Cd removal via scavenging by sinking particles can account for the observed apparent relative $\mathrm{Cd}$ depletion. If particle scavenging is the major cause of the relative $\mathrm{Cd}$ depletion, a lower 
$\mathrm{Cd}: \mathrm{PO} 4$ ratio in the OMZ than outside the OMZ would be expected because of the excessive $\mathrm{Cd}$ removal relative to PO4 by particle scavenging at the subsurface depths. However, when $\mathrm{Cd}: \mathrm{PO} 4$ ratio is plotted vs depth (Figure 3), such lower Cd:PO4 ratio is not observed in the OMZ (station USGT10-09 - USGT10-12). In contrast, the Cd:PO4 ratio in this region is similar to those outside the $\mathrm{OMZ}$ at similar depths (Figure 3), suggesting that the apparent relative $\mathrm{Cd}$ depletion in the $\mathrm{OMZ}$ may reflect a common depth dependent variation of $\mathrm{Cd}: \mathrm{PO} 4$ ratio, rather than a preferential $\mathrm{Cd}$ removal by particle scavenging.

As shown in Figure 3, Cd:PO4 ratio at stations in the OMZ increases with depth. Such depth dependent variation of $\mathrm{Cd}: \mathrm{PO} 4$ ratio is also observed at stations outside the $\mathrm{OMZ}$ and is similar to those reported in other oceanic regions (de Baar et al., 1994; Elderfield and Rickaby, 2000). It is likely that the apparent relative Cd depletion in the OMZ (Figure 2) is the commonly observed depth-dependent variation of $\mathrm{Cd}$ :PO4 ratio showing as an artefact of $\mathrm{Cd}$ depletion in the Cd-PO4 plot. The Cd concentration at upper thermocline depths of the OMZ falls below that predicted from the linear Cd-PO4 trend observed for stations outside the OMZ because of the low $\mathrm{Cd}: \mathrm{PO} 4$ ratios commonly observed at shallow depths combining with the high $\mathrm{Cd}$ and $\mathrm{PO} 4$ concentrations resulting from the enhanced regeneration of $\mathrm{Cd}$ and $\mathrm{PO} 4$ in the OMZ. As the data points at the upper thermocline depths of the OMZ have high $\mathrm{Cd}$ and PO4 concentration and low Cd:PO4 ratio, they tend to fall below those observed in the deep oceanic waters that have similar $\mathrm{Cd}$ and $\mathrm{PO} 4$ concentrations but higher $\mathrm{Cd}: \mathrm{PO} 4$ ratios. As shown in Figure 2, data points at the upper thermocline depths of the $\mathrm{OMZ}$ that show apparent relative Cd depletion tend to fall between two linear lines with slopes of $100 \mathrm{pM} / \mu \mathrm{M}$ and $200 \mathrm{pM} / \mu \mathrm{M}$ respectively. These slopes represent the Cd:PO4 ratios observed at 100-500 m depth at stations outside the OMZ, suggesting similar $\mathrm{Cd}: \mathrm{PO} 4$ ratio between the stations in the $\mathrm{OMZ}$ and the stations outside the 
OMZ. Thus, the apparent $\mathrm{Cd}$ depletion at the $\mathrm{Cd}$ maximum in the $\mathrm{OMZ}$ is likely to reflect a vertical regeneration feature showing as an artefact of Cd depletion in the Cd-PO4 plot. Such depth dependent variation of $\mathrm{Cd}: \mathrm{PO} 4$ ratio may also be responsible for the "kink" observed in the global Cd-PO4 plots (Boyle, 1988, de Baar et al., 1994) as the transition from low Cd:PO4 ratio in the upper water column to high $\mathrm{Cd}: \mathrm{PO} 4$ ratio in the deep ocean would produce this 'kink'.

The depth-dependent variation of $\mathrm{Cd}: \mathrm{PO} 4$ ratio is likely to result from the difference in the $\mathrm{Cd}: \mathrm{P}$ ratio in the POC sinking from the euphotic zone. As the majority of the POC is hydrated detritus that originates in plankton cell material and microbes, the light specific gravity of the POC make them difficult to sink unless they are aggregated and ballasted by heavier particles. If the two major groups of POC sinking from the surface ocean (Armstrong et al., 2002) have different $\mathrm{Cd}$ to phosphorus (P) ratios: the non-ballast POC containing a lower $\mathrm{Cd}: \mathrm{P}$ ratio and the ballast-associated $\mathrm{POC}$ containing a higher $\mathrm{Cd}: \mathrm{P}$ ratio, the regeneration of $\mathrm{Cd}$ and $\mathrm{P}$ from these POCs would fractionate Cd relative to $\mathrm{PO} 4$, increase $\mathrm{Cd}: \mathrm{PO} 4$ ratio with depth, and result in the coincident $\mathrm{Cd}$ and PO4 maxima observed in the global ocean (de Baar et al., 1994). This mechanism can be illustrated by simulating vertical profiles of $\mathrm{Cd}$ and $\mathrm{Cd}: \mathrm{PO} 4$ ratio determined in the North Atlantic (station USGT11-10 at $31.8^{\circ} \mathrm{N} 64.2^{\circ} \mathrm{W}$ ) and the North Pacific (at $30^{\circ} \mathrm{N} 145^{\circ} \mathrm{W}$ near SAFe station), using a "pipe" model applied along isopycnal surfaces.

In this model, subsurface waters of the ocean are considered to derive from the advection of source water from high latitude surface ocean along isopycnal surfaces. During the water transit at depths, the variation of $\mathrm{Cd}$ and $\mathrm{PO} 4$ concentration in the source water is determined by the difference between the regeneration of $\mathrm{Cd}$ and PO4 from POC remineralization and their removal by particle scavenging, according to the relationships: 


$$
\begin{aligned}
& \frac{d[P O 4]}{d t}=F_{P}-k_{P} \times[P O 4] \\
& \frac{d[C d]}{d t}=F_{C d}-k_{C d} \times[C d]
\end{aligned}
$$

where $\mathrm{F}_{\mathrm{P}}$ and $\mathrm{F}_{\mathrm{Cd}}$ represent the regeneration flux for $\mathrm{P}$ and $\mathrm{Cd}$ respectively, and $\mathrm{k}_{\mathrm{P}}$ and $\mathrm{k}_{\mathrm{Cd}}$ represent the scavenging rate constant for $\mathrm{P}$ and $\mathrm{Cd}$ respectively. The analytical solution for these equations are:

$$
\begin{aligned}
& {[P O 4]=[P O 4]^{0} \times e^{-k_{p} t}+\frac{F_{P}}{k_{P}}\left(1-e^{-k_{p} t}\right)} \\
& {[C d]=[C d]^{0} \times e^{-k_{C d} t}+\frac{F_{C d}}{k_{C d}}\left(1-e^{-k_{C d} t}\right)}
\end{aligned}
$$

where $[\mathrm{PO} 4]^{0}$ and $[\mathrm{Cd}]^{0}$ represent $\mathrm{PO} 4$ and $\mathrm{Cd}$ concentration in the source water and $\mathrm{t}$ is the water ventilation time.

The $\mathrm{Cd}$ and $\mathrm{P}$ regeneration fluxes $\mathrm{F}_{\mathrm{Cd}}$ and $\mathrm{F}_{\mathrm{P}}$ are assumed to result from the remineralization of two major groups of POC: the "excess" POC mainly composed of soft tissue organic matter $\left(\mathrm{F}_{\mathrm{P}}^{\text {excess }}\right.$ and $\left.\mathrm{F}_{\mathrm{Cd}}{ }^{\text {excess }}\right)$ and the "protected" $\mathrm{POC}$ mainly composed of organic matter that is associated with and protected by ballast minerals $\left(\mathrm{F}_{\mathrm{P}}^{\text {protected }}\right.$ and $\left.\mathrm{F}_{\mathrm{Cd}}{ }^{\text {protected }}\right)$ (Armstrong et al., 2002), according to the relationships:

$$
\begin{gathered}
F_{P}=F_{P}^{\text {excess }}+F_{P}^{\text {protected }} \\
F_{C d}=F_{C d}^{\text {excess }}+F_{C d}^{\text {protected }}
\end{gathered}
$$

Both $\mathrm{F}_{\mathrm{P}}{ }^{\text {excess }}$ and $\mathrm{F}_{\mathrm{P}}{ }^{\text {protected }}$ are assumed to decrease exponentially with depth following a power-law curve (Martin et al., 1987), according to the relationships:

$$
F_{P}^{\text {excess }}=F_{100}^{\text {excess }} \times\left(\frac{\text { Depth }}{100}\right)^{-b 1}
$$




$$
F_{P}^{\text {protected }}=F_{100}^{\text {protected }} \times\left(\frac{\text { Depth }}{100}\right)^{-b 2}
$$

Both $\mathrm{F}_{\mathrm{Cd}}^{\text {excess }}$ and $\mathrm{F}_{\mathrm{Cd}}$ protected are calculated from $\mathrm{F}_{\mathrm{P}}{ }^{\text {excess }}$ and $\mathrm{F}_{\mathrm{P}}^{\text {protected }}$ and the $\mathrm{Cd}: \mathrm{P}$ ratios in the POC fluxes: $[\mathrm{Cd} / \mathrm{P}]^{\text {excess }}$ and $[\mathrm{Cd} / \mathrm{P}]^{\text {protected }}$ according to the relationships:

$$
F_{C d}^{\text {excess }}=F_{P}^{\text {excess }} \times[C d / P]^{\text {excess }}
$$

$F_{C d}^{\text {protected }}=F_{P}^{\text {protected }} \times[C d / P]^{\text {protected }}$

The values of $[\mathrm{PO} 4]^{0},[\mathrm{Cd}]^{0}, \mathrm{t}, \mathrm{k}_{\mathrm{p}}$ and $\mathrm{k}_{\mathrm{Cd}}$ that are used in this simulation are listed in Tables 2 and their vertical distributions are shown in Figure 4. The preformed PO4, $[\mathrm{PO} 4]^{0}$, is estimated based on the relationship: $[\mathrm{PO} 4]=[\mathrm{PO} 4]^{0}-\frac{A O U}{138}$. The estimated $[\mathrm{PO} 4]^{0}$ increases with depth and has a lower value in the Atlantic $(\sim 0.9 \mu \mathrm{M})$ than in the Pacific $(\sim 1.1 \mu \mathrm{M})$ at $5000 \mathrm{~m}$.

The preformed $\mathrm{Cd},[\mathrm{Cd}]^{0}$, is estimated using the relationship: $[\mathrm{Cd}]^{0}=[\mathrm{PO} 4]^{0} \times \frac{[\mathrm{Cd}]^{0}}{[\mathrm{PO} 4]^{0}}$. For the western North Atlantic at $31.8^{\circ} \mathrm{N} 64.2^{\circ} \mathrm{W}$, the $[\mathrm{Cd}]^{0}:[\mathrm{PO} 4]^{0}$ ratio increases linearly with depth from $100 \mathrm{pM} / \mu \mathrm{M}$ at $100 \mathrm{~m}$ to $300 \mathrm{pM} / \mu \mathrm{M}$ at $750 \mathrm{~m}$, decrease to $220 \mathrm{pM} / \mu \mathrm{M}$ at $2000 \mathrm{~m}$ and then increase to $300 \mathrm{pM} / \mu \mathrm{M}$ at $5000 \mathrm{~m}$. The $[\mathrm{Cd}]^{0}:[\mathrm{PO} 4]^{0}$ values at 700,2000 and $5000 \mathrm{~m}$ represent the typical ratios measured in the Antarctic Intermediate Water, North Atlantic Deep Water and Antarctic Bottom Water respectively (de baar et al., 1994; Elderfield and Rickaby, 2000). For the North Pacific at $30^{\circ} \mathrm{N} 145^{\circ} \mathrm{W}$, the $[\mathrm{Cd}]^{0}:[\mathrm{PO} 4]^{0}$ ratio increases linearly with depth from $100 \mathrm{pM} / \mu \mathrm{M}$ at $100 \mathrm{~m}$ to $300 \mathrm{pM} / \mu \mathrm{M}$ at $750 \mathrm{~m}$, and then remains constant at 300 $\mathrm{pM} / \mu \mathrm{M}$ at depths below $750 \mathrm{~m}$. The $[\mathrm{Cd}]^{0}:[\mathrm{PO} 4]^{0}$ value of $300 \mathrm{pM} / \mu \mathrm{M}$ at depths below $750 \mathrm{~m}$ represents the ratio in the source water from the Southern Ocean (de Baar et al., 1994; Elderfield and Rickaby, 2000).

The mean water ventilation time $\mathrm{t}$ in Table 2 is estimated using a combination of ${ }^{3} \mathrm{H}-{ }^{3} \mathrm{He}$ age, CFC age, and ${ }^{14} \mathrm{C}$ mean age (Stuiver et al., 1983; Jenkins, 1998; Smethie et al., 2000; Fine et al., 2002; Khatiwala et al., 2012 ) tuned to obtain the same $\mathrm{F}_{\mathrm{P}}{ }^{\text {excess }}$ and $\mathrm{F}_{\mathrm{P}}{ }^{\text {protected }}$ in the North Atlantic as in the North Pacific. The mean water residence time estimated in this way is $280 \mathrm{yr}$ for the North Atlantic at $5000 \mathrm{~m}$ and $820 \mathrm{yr}$ for the North Pacific at $5000 \mathrm{~m}$ which are consistent with those estimated by Stuiver et al. (1983). Phosphate scavenging rate constant $\mathrm{k}_{\mathrm{p}}$ is assumed 
to be equal to cadmium scavenging rate constant $\mathrm{k}_{\mathrm{Cd}}$. Both $\mathrm{k}_{\mathrm{p}}$ and $\mathrm{k}_{\mathrm{Cd}}$ are assumed to vary in proportion to the sum of $\mathrm{F}_{\mathrm{p}}^{\text {excess }}$ and $\mathrm{F}_{\mathrm{P}}^{\text {protected }}$, to achieve a scavenging residence time of $\sim 50 \mathrm{ky}$ at $5000 \mathrm{~m}$, which falls within the reported oceanic residence time of 20-100 kyr for P and $\sim 50 \mathrm{ky}$ for Cd (Boyle et al., 1976; Paytan and McLaughlin, 2007).

In the model simulation, we first estimate the values of $\mathrm{F}_{100}{ }^{\text {excess }}, \mathrm{F}_{100}{ }^{\text {protected }}$, b1 and b2 by matching the simulated [PO4] to the measured [PO4], and then use these values to calculate $[\mathrm{Cd} / \mathrm{P}]^{\text {excess }}$ and $[\mathrm{Cd} / \mathrm{P}]^{\text {protected }}$ by matching the simulated $[\mathrm{Cd}]$ to the measured $[\mathrm{Cd}]$. Based on the values of $[\mathrm{PO} 4]^{0},[\mathrm{Cd}]^{0}, \mathrm{t}, \mathrm{k}_{\mathrm{p}}$ and $\mathrm{k}_{\mathrm{Cd}}$ in Tables 2 , we obtain $\mathrm{F}_{100}$ excess of $0.4 \mu \mathrm{M} / \mathrm{yr}, \mathrm{F}_{100}$ protected of $0.046 \mu \mathrm{M} / \mathrm{yr}$, b1 of $3.5, \mathrm{~b} 2$ of $0.84,[\mathrm{Cd} / \mathrm{P}]^{\text {excess }}$ of $30 \mathrm{pM} / \mu \mathrm{M}$ for both the North Atlantic and the North Pacific, $[\mathrm{Cd} / \mathrm{P}]^{\text {protected }}$ of $210 \mathrm{pM} / \mu \mathrm{M}$ for the North Atlantic, and $[\mathrm{Cd} / \mathrm{P}]^{\text {protected }}$ of 340 $\mathrm{pM} / \mu \mathrm{M}$ for the North Pacific. The vertical distribution of $\mathrm{F}_{\mathrm{P}}{ }^{\text {excess }}, \mathrm{F}_{\mathrm{P}}{ }^{\text {protected }}$, measured and modeled [PO4], [Cd] and Cd:PO4 ratio are shown in Figure 4. The Cd vs PO4 plot is shown in Figure 5.

The above results indicate that the non-ballast POC export that is higher at the surface but attenuates faster with depth $\left(F_{P}^{\text {excess }}=0.4 \times\left(\frac{\text { Depth }}{100}\right)^{-3.5}\right)$ has a low $[\mathrm{Cd} / \mathrm{P}]^{\text {excess }}(30 \mathrm{pM} / \mu \mathrm{M})$, and that the ballast-associated POC export that is a lower at the surface and attenuates more slowly with depth $\left(F_{P}^{\text {protected }}=0.046 \times\left(\frac{\text { Depth }}{100}\right)^{-0.84}\right)$ has a $[\mathrm{Cd} / \mathrm{P}]^{\text {protected }}$ ratio that is higher in the North Pacific $(340 \mathrm{pM} / \mu \mathrm{M})$ than the North Atlantic $(210 \mathrm{pM} / \mu \mathrm{M})$. The $[\mathrm{Cd} / \mathrm{P}]^{\text {excess }}$ value is lower than $[\mathrm{Cd} / \mathrm{P}]^{\text {protected }}$ because a $[\mathrm{Cd} / \mathrm{P}]^{\text {excess }}$ ratio lower than or equal to $[\mathrm{Cd} / \mathrm{P}]^{\text {protected }}$ would result in a Cd:PO4 maximum in the upper water column. The $[\mathrm{Cd} / \mathrm{P}]^{\text {protected }}$ value is higher in the North Pacific than the North Atlantic because a higher $[\mathrm{Cd} / \mathrm{P}]^{\text {protected }}$ in the North Atlantic than North Pacific would result in a higher Cd:PO4 ratio in the deep North Atlantic than the deep North Pacific.

The lower $[\mathrm{Cd} / \mathrm{P}]^{\text {excess }}(30 \mathrm{pM} / \mu \mathrm{M})$ than $[\mathrm{Cd} / \mathrm{P}]^{\text {protected }}(210-340 \mathrm{pM} / \mu \mathrm{M})$ is consistent with the observation that a larger percentage of $\mathrm{P}$ than $\mathrm{Cd}$ is released from plankton samples to 
the seawater suspension during the two hours it took to get the samples into the ship's laboratory for processing (Collier and Edmond, 1984), suggesting that more $\mathrm{P}$ than $\mathrm{Cd}$ would be released into the shallow water column as the POC sinks. The lower $[\mathrm{Cd} / \mathrm{P}]^{\text {excess }}(30 \mathrm{pM} / \mu \mathrm{M})$ than $[\mathrm{Cd} / \mathrm{P}]^{\text {protected }}(210-340 \mathrm{pM} / \mu \mathrm{M})$ is also consistent with results of laboratory culture experiments (Lane et al., 2009). Lane et al. (2009) showed that Phaeocystis P. Pouchetti solitary cells that have sinking rates of less than $1 \mathrm{~m}$ /day (Becquevort and Smith, 2001; Peperzak et al., 2003) has a low intracellular $\mathrm{Cd} / \mathrm{P}$ ratio of $13-23 \mathrm{pM} / \mu \mathrm{M}$.

The lower $[\mathrm{Cd} / \mathrm{P}]^{\text {protected }}$ in the North Atlantic than in the North Pacific may be expected in light of contrasting distribution of biogenic opal and biogenic $\mathrm{CaCO}_{3}$ between the two oceans. Although $\mathrm{CaCO}_{3}$ and opal are not significant carriers of $\mathrm{Cd}$, these minerals can act as ballast for POC sinking to the oceanic interior. While the entire Atlantic Ocean is depleted with regard to biogenic Si export flux and enriched in coccolithphore $\mathrm{CaCO}_{3}$, the dominant ballast mineral responsible for carbon export is diatom opal in the North Pacific (Honjo et al., 2008). Thus, if $\mathrm{Cd}: \mathrm{P}$ ratio in the POC associated with opal ballast is higher than the ratio in the POC associated with $\mathrm{CaCO}_{3}$ ballast, the deep water $\mathrm{Cd}: \mathrm{PO} 4$ ratio would be higher in the North Pacific than in the North Atlantic. This hypothesis is consistent with higher intracellular Cd/P ratio for diatom $\mathrm{T}$. oceanica (540-1100 pM/ $\mu \mathrm{M})$ than for coccolithophore E. huxleyi $(320-610 \mathrm{pM} / \mu \mathrm{M})$ determined in laboratory culture expriments (Lane et al., 2009, Finkel et al., 2007; Ho et al., 2003).

Bruland and Franks (1983) and Sherrell and Boyle (1992) reported that in the North Atlantic the seawater dissolved Cd to PO4 ratio is similar to the $\mathrm{Cd}: \mathrm{PO} 4$ ratio of suspended particles at each depth throghout the water column. The compositions of sinking $(>51 \mu \mathrm{m})$ and suspended $(>1-51 \mu \mathrm{m})$ particulate matters were also determined along the GEOTRACES GA03 section. Data are available at BCO-DMO website: (http://osprey.bco-dmo.org/dataset.cfm?id= 
14219\&flag=viewa and http://osprey.bco-dmo.org/dataset.cfm?id=14220\&flag=viewa). The slope of particulate $\mathrm{Cd}$ vs particulate $\mathrm{P}$ plot reflects the ratio of $\mathrm{Cd}$ to $\mathrm{P}$ net exchange among sinking $(>51 \mu \mathrm{m})$ and suspended $(>1-51 \mu \mathrm{m})$ particulate and dissolved phases, and this slope in entire water column at offshore stations (USGT11-12, 14, 18, 20, 22) is $130 \pm 6.6 \mu \mathrm{mol} / \mathrm{mol}(1 \sigma)$ and $48.3 \pm 11.8 \mu \mathrm{mol} / \mathrm{mol}(1 \sigma)$ for sinking and suspended particles respectively. These values are in good agreement with $\mathrm{Cd} / \mathrm{P}$ regeneration ratios used in the model. Relatively low standard deviation of the above slopes $(6.6 / 130=5 \%$ and $11.8 / 48.3=24 \%)$ indicates high correlation between particulate $\mathrm{Cd}$ and $\mathrm{P}$ and supports our hypothesis that particles are the major cause of strong Cd-P correlation in dissolved phase. Nonetheless there are two reasons that may make particulate ratios differ from the ratios inferred from the model. First, the change of $\mathrm{Cd}$ and $\mathrm{P}$ concentration of sinking and suspended particles reflects the net changes in the combined effect of remineralization, aggregation/dis-aggregation and scavenging processes, whereas the $\mathrm{Cd} / \mathrm{P}$ regeneration ratios used in our model reflect only the $\mathrm{Cd} / \mathrm{P}$ ratios in the remineralization flux. Second, the categorization of particles in our model is not based upon particle size. In other words, the protected vs. excess characteristics of particles may not result in their size characteristics. Despite the similarity between determined particulate $\mathrm{Cd} / \mathrm{P}$ ratios and the regeneration ratios used in our model, particulate $\mathrm{Cd} / \mathrm{P}$ ratios cannot be linked directly to the dissolved Cd/P ratios. Further studies are needed to determine $\mathrm{Cd} / \mathrm{P}$ ratio in "protected" and "excess" particles.

Our hypothesis that the $\mathrm{Cd}: \mathrm{PO} 4$ ratio in the deep nutrient regeneration flux is lower in the North Atlantic than in the North Pacific is consistent with the scenario where high eolian $\mathrm{Fe}$ deposition to the North Atlantic (Duce et al., 1986) relieves Fe limitation of marine phytoplankton and decreases their intracellular Cd/P ratio (Cullen et al., 2003; Lane et al., 2009). 
A lower $[\mathrm{Cd} / \mathrm{P}]^{\text {protected }}$ in the North Atlantic than the North Pacific is required to balance the $\mathrm{Cd}$ and PO4 supply to the North Atlantic via Subantarctic Mode Water (SAMW, Williams et al., 2006). The SAMW tends to have a lower Cd:PO4 ratio than AAIW and AABW, because Cd:PO4 ratio in oceanic surface water increases with latitude (Elderfield and Rcikaby, 2000) and the SAMW originates from lower latitude than the AAIW and AABW (Hanawa and Talley, 2001; Drijfhout et al., 2005). As Cd:PO4 ratio in the deep North Pacific is high ( $350 \mathrm{pM} / \mu \mathrm{M}$ as compared to $\sim 200 \mathrm{pM} / \mu \mathrm{M}$ for the deep North Atlantic, Löscher et al., 1997; Elderfield and Rickaby, 2000), a high $[\mathrm{Cd} / \mathrm{P}]^{\text {protected }}$ in the North Pacific is needed to balance the upward flux of $\mathrm{Cd}$ and $\mathrm{PO} 4$ from the subsurface ocean in this region. If $[\mathrm{Cd} / \mathrm{P}]^{\text {protected }}$ is lower than the $\mathrm{Cd}: \mathrm{PO} 4$ ratio in the upward $\mathrm{Cd}$ and $\mathrm{PO} 4$ flux, the removal of $\mathrm{Cd}$ and $\mathrm{PO} 4$ by biological growth would result in a high $\mathrm{Cd}: \mathrm{PO} 4$ ratio in the dissolved $\mathrm{Cd}$ and $\mathrm{PO} 4$ pool remaining in the surface water. The surface return flow that carries this $\mathrm{Cd}$ and $\mathrm{PO} 4$ pool of high Cd:PO4 ratio to the North Atlantic would lead to a high Cd:PO4 ratio in the subsurface waters of the North Atlantic, but such high Cd:PO4 ratio has not been reported in the present-day North Atlantic. If the POC export to the upper ocean has a lower $\mathrm{Cd}: \mathrm{PO} 4$ ratio than the $\mathrm{POC}$ export to the deeper ocean, the return flow from the North Pacific to the Atlantic in near surface currents will carry this low $\mathrm{Cd}: \mathrm{PO} 4$ ratio to the Atlantic resulting in a lower Cd:PO4 ratio in the deep North Atlantic.

If global Cd vs P relationship is controlled mainly by algal species composition in the euphotic zone (diatoms, coccolithophore and the algal species producing non-ballast POC), rather than Rayleigh type preferential Cd uptake (Elderfield and Rickaby, 2000) or enhanced Cd uptake during Zn or Fe limitation (Sunda and Huntsman, 2000; Cullen et al., 2003; Lane et al., 2009), one would expect an influence of dissolved Cd:PO4 ratio in the Southern Ocean surface water by the northward transition of the dominant form of carbon export from biogenic opal- 
associated ballast POC export at the high latitude, to biogenic $\mathrm{CaCO}_{3}$-associated ballast $\mathrm{POC}$ export and non- ballast associated POC export at the lower latitudes (Honjo et al., 2008), by an enhanced opal-associated export production resulting from the relaxation of Fe-limitation during last glacial maximum (LGM) (Martin, 1990), and by a switch in species composition and reduced diatom export production south of the APF during the LGM (Mortlock et al., 1991). An integration of such influences into models of Cd:PO4 ratio in the Southern Ocean surface water that considers the $\mathrm{Cd}$ and $\mathrm{PO} 4$ supply via upward mixing would be necessary to properly use $\mathrm{Cd}: \mathrm{P}$ ratio recorded in planktonic foraminifera to infer paleo-PO4 utilization in the Southern Ocean. Future studies are needed to further examine these hypothesis.

\section{Acknowledgements}

We would like to thank J. Fitzsimmons, P. Morton, E. Boyle, A. Aguila-Islas, Mariko Hatta and Chris Measures for sample collection, filtration and acidification, and the chief scientists E. Boyle, B. Jenkins and G. Cutter, and the crews of the R/V Knorr for the help in sample collection. This work was supported by NSF grant OCE-1132752. 


\section{References}

Armstrong, R.A., Lee, C., Hedges, J.I., Honjo, S.,Wakeham, S.G., 2002. A new, mechanistic model for organic carbon fluxes in the ocean based on the quantitative association of POC with ballast minerals. Deep-Sea Res. II 49, 219-236.

Becquevort, S., Smith Jr., W.O., 2001. Aggregation, sedimentation and biodegradability of phytoplankton-derived material during spring in the Ross Sea, Antarctica. Deep-Sea Res. II 48, 4155-4178.

Boyle, E.A., Huested, S.S., Jones, S.P., 1981. On the distribution of copper, nickel, and cadmium in the surface waters of the North Atlantic and North Pacific Ocean. J. Geophys. Res., 86, C9, 8048-8066Boyle, E.A.,1988. Cadmium: chemical tracer of deepwater paleoceanography. Paleoceanography 3, 471-489.

Boyle, E.A., Sclater, F., Edmond, J.M., 1976. On the marine geochemistry of cadmium. Nature $263,42-44$.

Bruland, K.W., 1980. Oceanographic distributions of cadmium, zinc, nickel, and copper in the North Pacific. Earth Planet. Sci. Len. 47, 176-198.

Bruland, K.W., Franks, R.P., 1983. Mn, Ni, Cu, Zn, and Cd in the western North Atlantic, in: Trace Metals in Sea Water (NATO Conf. Ser.), C.S. Wong, E. Boyle, K.W. Bruland, Burton, T.D. and E.D. Goldberg, eds., pp. 395-414, Plenum.

Collier, R., Edmond, J.M., 1984. The trace element geochemistry of marine biogenic particulate matter. Prog. Oceanog. 13, 113-199.

Cullen, J.T., 2006. On the nonlinear relationship between dissolved cadmium and phosphate in the modern global ocean: could chronic iron limitation of phytoplankton growth cause the kink? Limnol. Oceanogr. 51, 1369-1380. 
Cullen, J.T., Chase, Z., Coale, K.H., Fitzwater, S., Sherrell, R.M., 2003. Effect of iron limitation on the cadmium to phosphorus ratios of natural phytoplankton assemblages from the Southern Ocean. Limnol. Oceanogr. 48, 1079-1087.

Cullen, J.T., Sherrell, R.M., 2005. Effects of dissolved carbon dioxide, zinc, and manganese on the cadmium to phosphorus ratio in natural phytoplankton assemblages. Limnol. Oceanogr. 50, 1193-1204.

De Baar, H.J.W., Saager, P.M., Notling, R.F., Van Der Meer, J., 1994. Cadmium versus phosphate in the world ocean. Mar. Chem. 46, 261-281.

Drijfhout, S.S., Donners, J.M.H., de Ruijter, W.P.M., 2005. The origin of Intermediate and Subpolar Mode Waters crossing the Atlantic equator in OCCAM, Geophys. Res. Lett., 32, L06602, doi:10.1029/2004GL021851.

Duce, R.A., Tindale, N.W., 1986. Atmospheric transport of iron and its deposition in the ocean. Limnol. Oceanogr., 36, 1715-1726.

Elderfield, H., Rickaby, R.E.M., 2000. Oceanic Cd/P ratio and nutrient utilization in the glacial Southern Ocean. Nature 405, 305-310.

Fine, R.A., Rhein, M., Andrie, C. 2002. Using a CFC effective age to estimate propagation and storage of climate anomalies in the deep western North Atlantic Ocean. Geophys. Res. Lett. 29, 2227, doi:10.1029/2002GL015618.

Finkel, Z.V., Quigg, A.S., Chiampi, R.K., Schofield, O.E., Falkowski, P.G., 2007. Phylogenetic diversity in cadmium : phosphorus ratio regulation by marine phytoplankton, Limnol. Oceanog., 52(3), 1131-1138.

Frew, R.D. 1995. Antarctic bottom water formation and the global cadmium to phosphorus relationship. Geophys. Res. Lett. 22, 2349-2352.

Frew, R.D., Hunter, K.H., 1992. Influence of Southern Ocean waters on the cadmium-phosphate properties of the global ocean. Nature 360, 144-146. 
Hanawa, K., Talley, T.D. 2001. Mode waters, in Ocean Circulation and Climate: Observing and Modelling of the Global Ocean, edited by G. Siedler, J. Church, and J. Gould, pp. 373386, Elsevier, New York.

Ho, T. Y., Quigg, A., Finkel, Z.V., Milligan, A,J., Wyman, K., Falkowski, P. G., Morel, F.M.M., 2003. The elemental composition of some marine phytoplankton, Journal of Phycology, 39(6), 1145-1159.

Honjo, S., Manganini, S.J., Krishfield, R.A., Francois, R., 2008. Particulate organic carbon fluxes to the ocean interior and factors controlling the biological pump: A synthesis of global sediment trap programs since 1983. Progress in Oceanography 76, 217-285.

Jenkins, W.J., 1998. Studying subtropical thermocline ventilation and circulation using tritium and ${ }^{3}$ He. Journal of Geophysical Research, 103, C8, 15,817-15,831.

Khatiwala, S., Primeau F, Holzer, M., 2012. Ventilation of the deep ocean constrained with tracer observations and implications for radiocarbon estimates of ideal mean age. Earth Planet. Sci. Len. 325-326, 116-125.

Lane, E.S., Semeniuk, D.M., Strzepek, R.F., Cullen, J.T., Maldonado, M.T., 2009. Effects of iron limitation on intracellular cadmium of cultured phytoplankton: Implications for surface dissolved cadmium to phosphate ratios. Mar. Chem. 115, 155-162.

Löscher, B.M., van der Meer, J., de Baar, H.J.W., Saager, P.M., de Jong, J.T.M., 1997. The global $\mathrm{Cd} /$ phosphate relationship in deep ocean waters and the need for accuracy. Mar. Chem. 59, 87-93.

Martin, J.H., Gordon, R.M., Fitzwater, S., 1990. Iron in Antarctic waters. Nature 345, 156-158.

Martin, J.H., Knauer, G.A., Karl, D.M., Broenkow, W.W., 1987. VERTEX: Carbon cycling in the northeast Pacific. Deep-Sea Res. 34, 261-285.

Mortlock, R.A., Charles, C.D., Froelich, P.N., Zibello, M.A., Saltzman, J., Hays, J.D., Burckle, L.H., 1991. Evidence for lower productivity in the Antarctic ocean during last glaciation. Nature 351, 220-223. 
Paytan, A., McLaughlin, K. 2007. The Oceanic Phosphorus Cycle. Chem. Rev. 2007, 107, 563-576.

Peperzak, L., Colijn, F.R.K., Gieskes, W.W.C., Joordens, J.C.A., 2003. Phytoplankton sinking rates in the Rhine region of freshwater influence. J. Plank. Res. 25, 365-383.

Saager, P.M., de Baar, H.J.W., 1993. Limitations to the quantitative application of Cd as a paleoceanographic tracer, based on results of a multi-box model (MENU) and statistical considerations. Global Planet. Change 8, 69-92.

Sherrell, R.M., Boyle, E.A., 1992. The trace metal composition of suspended particles in the oceanic water column near Bermuda, Earth and Planetary Science Letters, 111: 155174.

Smethie, W. M., Fine, R.A., Putzka, A., Jones, E.P., 2000. Tracing the flow of North Atlantic deep water using chlorofluorocarbons, J. Geophys. Res., 105, 14,297-14,323,

Stramma, L. et al., 2008. Oxygen minimum zones in the North Atlantic south and east of the Cape Verde Islands. Journal of Geophysical Research, 113: C04014.

Strickland, J.D., Parsons, T.R., 1972. A Practical Handbook of Seawater Analysis. Minister of Supply and Services Canada 1977.

Stuiver, M., Quay, P.D., Ostlund, H.G., 1983. Abyssal water carbon-14 distribution and the age of the world oceans, Science, 219, 849-851.

Sunda, W.G., Huntsman, S.A., 2000. Effect of Zn, Mn, and Fe on Cd accumulation in phytoplankton: Implications for oceanic Cd cycling. Limnol. Oceanogr. 45, 1501-1516. 
Williams, R.G., Roussenov, V., Follows, M.J. 2006. Nutrient streams and their induction into the mixed layer. Global Biogeochemical Cycles, 20, GB1016, doi:10.1029/2005GB002586.

Wu, J., E,A. Boyle, 1997. Low blank preconcentration technique for the determination of lead, copper and cadmium in small-volume seawater samples by isotope dilution ICPMS. Anal. Chem. 69:2464-2470.

Yeats, P.A., 1998. An isopycnal analysis of cadmium distributions in the Atlantic Ocean. Marine Chemistry 61: 15-23. 


\section{Figure captions}

\section{Fig. 1a}

Dissolved $\mathrm{O}_{2}$ distribution at $400 \mathrm{~m}$ depth from the WOCE dataset with sampling station location shown as black and red filled circles for US GEOTRACES 2010 and 2011 cruises respectively. The term "USGT10-" for the 2010 cruise and "USGT11-" for the 2011 cruise are omitted from the station number label because of space limitation in the plot. Station USGT01-24 is label in white as it is at the same location as USGT10-12.

\section{Fig. 1b}

Dissolved Cd distribution in the tropical-subtropical North Atlantic along GEOTRACES GA03 section during US GEOTRACES 2010 and 20011 cruises showing a subsurface Cd maximum extending from the $\mathrm{OMZ}$ at the eastern boundary.

\section{Fig. 1c}

Phosphate distribution in the tropical-subtropical North Atlantic along GEOTRACES GA03 section during US GEOTRACES 2010 and 2011 cruises showing a subsurface maximum in the $\mathrm{OMZ}$ at the eastern boundary coinciding with the $\mathrm{Cd}$ maximum.

\section{Fig. 1d}

AOU distribution in the tropical-subtropical North Atlantic along GEOTRACES GA03 section during US GEOTRACES 2010 and 2011 cruises showing a subsurface AOU maximum in the $\mathrm{OMZ}$ at the eastern boundary coinciding with the $\mathrm{Cd}$ and PO4 maxima.

\section{Fig. 1e}

Dissolved $\mathrm{O}_{2}$ distribution in the tropical-subtropical North Atlantic along GEOTRACES GA03 section during US GEOTRACES 2010 and 2011 cruises showing a subsurface dissolved $\mathrm{O}_{2}$ minimum in the $\mathrm{OMZ}$ at the eastern boundary coinciding with the $\mathrm{Cd}$ and PO4 maxima and AOU maximum. 


\section{Fig. 2}

Cd vs PO4 plot showing linear relationship between $\mathrm{Cd}$ and PO4 outside the OMZ as represented by the black solid lines, and the apparent Cd depletion relative to PO4 in the upper thermocline waters of the $\mathrm{OMZ}$ as shown by data points below the black solid lines. The two red dash lines that have the slope of $100 \mathrm{pM} / \mu \mathrm{M}$ and $200 \mathrm{pM} / \mu \mathrm{M}$ represent the range of $\mathrm{Cd}: \mathrm{PO} 4$ ratio for waters in the upper thermocline.

\section{Fig. 3}

Cd:PO4 ratio distribution in the tropical-subtropical North Atlantic along GEOTRACES GA03 section during US GEOTRACES 2010 and 2011 cruises showing increasing Cd:PO4 ratio with depth. A Cd depletion relative to PO4 is not observed at the OMZ.

\section{Fig. 4a}

Comparison of preformed PO4, measured PO4 and model PO4 in the North Atlantic $\left(31.7521^{\circ} \mathrm{N}, 64.1720^{\circ} \mathrm{W}\right.$, Stn USGT $\left.11-10\right)$ and the North Pacific $\left(32.8^{\circ} \mathrm{N}, 145^{\circ} \mathrm{W}\right.$, Bruland, 1980). The data in this plot are listed in Table 2.

\section{Fig. 4b}

Comparison of preformed Cd, measured Cd and model Cd in the North Atlantic $\left(31.7521^{\circ} \mathrm{N}\right.$, 64.1720 $\mathrm{W}$, Stn USGT 11-10) and the North Pacific $\left(32.8^{\circ} \mathrm{N}, 145^{\circ} \mathrm{W}\right.$, Bruland, 1980$)$. The data in this plot are listed in Table 2.

\section{Fig. 4c}

Ventilation time in the North Atlantic and the North Pacific that are used in the model simulation. The data in this plot are listed in Table 2. 


\section{Fig. 4d}

The scavenging residence time of PO4 $\left(1 / \mathrm{k}_{\mathrm{p}}\right)$ and $\left.\mathrm{Cd}\left(1 / \mathrm{k}_{\mathrm{Cd}}\right)\right)$ used in the model simulation. The data for this plot are listed in Table 2.

\section{Fig. $4 \mathrm{e}$}

POC export flux used in the model simulation. The "excess" POC that is mainly composed of soft tissue organic matter follows the relationship: $F_{P}^{\text {excess }}=0.4 \times\left(\frac{\text { Depth }}{100}\right)^{-3.5}$. The "protected" POC that is mainly composed of organic matter and is associated with and protected by ballast minerals follows the relationship: $F_{P}^{\text {protected }}=0.046 \times\left(\frac{\text { Depth }}{100}\right)^{-0.84}$. The data in this plot are listed in Table 2.

\section{Fig. $4 f$}

Comparison of measured Cd:PO4 ratio with modeled Cd:PO4 ratio for the North Atlantic $\left(31.75^{\circ} \mathrm{N}, 64.17^{\circ} \mathrm{W}\right.$, Stn USGT $\left.11-10\right)$ and the North Pacific $\left(32.80^{\circ} \mathrm{N}, 144.90^{\circ} \mathrm{W}\right.$, Bruland, 1980). The model simulation uses a $[\mathrm{Cd} / \mathrm{P}]^{\text {excess }}$ of $30 \mathrm{pM} / \mu \mathrm{M}$ for both the Atlantic and Pacific and $\mathrm{a}[\mathrm{Cd} / \mathrm{P}]^{\text {protected }}$ of $210 \mathrm{pM} / \mu \mathrm{M}$ for the Atlantic and $340 \mathrm{pM} / \mu \mathrm{M}$ for the Pacific. The data in this plot are listed in Table 2. The Cd-PO4 plot based on these data is shown in Figure 5.

\section{Fig. 5}

Cd-PO4 plot for the North Atlantic $\left(31.75^{\circ} \mathrm{N}, 64.17^{\circ} \mathrm{W}\right.$, Stn USGT 11-10) and the North Pacific $\left(32.80^{\circ} \mathrm{N}, 144.90^{\circ} \mathrm{W}\right.$, Bruland, 1980) showing a "kink" at $\sim 1.3 \mu \mathrm{M}$ PO4. The model simulation uses a $[\mathrm{Cd} / \mathrm{P}]^{\text {excess }}$ of $30 \mathrm{pM} / \mu \mathrm{M}$ for both the Atlantic and Pacific and a $[\mathrm{Cd} / \mathrm{P}]^{\text {protected }}$ of 210 $\mathrm{pM} / \mu \mathrm{M}$ for the Atlantic and $340 \mathrm{pM} / \mu \mathrm{M}$ for the Pacific. The data in this plot are listed in Table 2. 
Table 1. Summary of water column Cd data

\begin{tabular}{|c|c|c|c|}
\hline Station ID & $\begin{array}{c}\text { Depth } \\
\text { (m) }\end{array}$ & $\begin{array}{c}\text { Cd } \\
(\mathbf{p M})\end{array}$ & $\begin{array}{l}\text { PO4 } \\
(\mu \mathrm{M})\end{array}$ \\
\hline USGT10-01 & 24 & 8 & 0.01 \\
\hline \multirow[t]{20}{*}{$\left(38.32^{\circ} \mathrm{N}, 9.66^{\circ} \mathrm{W}\right)$} & 35 & 12 & 0.07 \\
\hline & 40 & 12 & 0.06 \\
\hline & 68 & 5 & 0.11 \\
\hline & 136 & 41 & 0.39 \\
\hline & 199 & 72 & 0.51 \\
\hline & 300 & 114 & 0.64 \\
\hline & 401 & 155 & 0.79 \\
\hline & 506 & 176 & 0.85 \\
\hline & 642 & 121 & 0.66 \\
\hline & 777 & 136 & 0.69 \\
\hline & 876 & 149 & 0.76 \\
\hline & 900 & 150 & 0.74 \\
\hline & 990 & 148 & 0.74 \\
\hline & 1150 & 152 & 0.75 \\
\hline & 1293 & 202 & 0.93 \\
\hline & 1480 & 188 & 0.93 \\
\hline & 1701 & 246 & 1.13 \\
\hline & 1901 & 260 & 1.21 \\
\hline & 2101 & 289 & 1.27 \\
\hline & 2301 & 284 & 1.32 \\
\hline
\end{tabular}




\begin{tabular}{|c|c|c|c|}
\hline & 2501 & 301 & 1.36 \\
\hline & 2601 & 315 & 1.38 \\
\hline & 2701 & 332 & 1.40 \\
\hline USGT10-03 & 35 & 2 & 0.00 \\
\hline$\left(35.20^{\circ} \mathrm{N}, 16.00^{\circ} \mathrm{W}\right)$ & 51 & 2 & 0.01 \\
\hline & 77 & 2 & 0.02 \\
\hline & 100 & 18 & 0.23 \\
\hline & 136 & 32 & 0.30 \\
\hline & 191 & 54 & 0.40 \\
\hline & 301 & 115 & 0.61 \\
\hline & 401 & 133 & 0.68 \\
\hline & 490 & 176 & 0.86 \\
\hline & 611 & 223 & 0.99 \\
\hline & 777 & 233 & 1.08 \\
\hline & 876 & 243 & 1.08 \\
\hline & 994 & 232 & 1.06 \\
\hline & 1051 & 229 & 1.07 \\
\hline & 1201 & 247 & 1.11 \\
\hline & 1351 & 247 & 1.14 \\
\hline & 1501 & 251 & 1.14 \\
\hline & 1701 & 270 & 1.18 \\
\hline & 1901 & 284 & 1.22 \\
\hline & 2101 & 292 & 1.26 \\
\hline & 2300 & 297 & 1.30 \\
\hline & 2501 & 309 & 1.34 \\
\hline
\end{tabular}




\begin{tabular}{|c|c|c|c|}
\hline & 2601 & 335 & 1.36 \\
\hline & 2681 & 347 & 1.38 \\
\hline USGT10-05 & 31 & 2 & 0.00 \\
\hline \multirow[t]{22}{*}{$\left(31.00^{\circ} \mathrm{N}, 22.00^{\circ} \mathrm{W}\right)$} & 52 & 2 & 0.00 \\
\hline & 81 & 3 & 0.00 \\
\hline & 101 & 2 & 0.01 \\
\hline & 136 & 15 & 0.15 \\
\hline & 187 & 24 & 0.20 \\
\hline & 251 & 46 & 0.35 \\
\hline & 351 & 76 & 0.48 \\
\hline & 553 & 165 & 0.81 \\
\hline & 802 & 294 & 1.29 \\
\hline & 963 & 298 & 1.32 \\
\hline & 1202 & 298 & 1.26 \\
\hline & 1501 & 275 & 1.24 \\
\hline & 1800 & 279 & 1.23 \\
\hline & 2100 & 302 & 1.28 \\
\hline & 2401 & 318 & 1.32 \\
\hline & 2701 & 336 & 1.37 \\
\hline & 3001 & 352 & 1.42 \\
\hline & 3301 & 366 & 1.46 \\
\hline & 3600 & 379 & 1.49 \\
\hline & 3899 & & 1.50 \\
\hline & 4199 & 381 & 1.51 \\
\hline & 4549 & 403 & 1.51 \\
\hline
\end{tabular}




\begin{tabular}{|c|c|c|c|}
\hline & 4899 & 404 & 1.51 \\
\hline USGT10-07 & 35 & 2 & 0.09 \\
\hline \multirow[t]{23}{*}{$\left(24.00^{\circ} \mathrm{N}, 22.00^{\circ} \mathrm{W}\right)$} & 46 & 2 & 0.06 \\
\hline & 71 & 2 & 0.10 \\
\hline & 152 & 94 & 0.96 \\
\hline & 202 & 127 & 0.94 \\
\hline & 353 & 193 & 0.98 \\
\hline & 400 & 205 & 0.97 \\
\hline & 454 & 309 & 1.35 \\
\hline & 504 & 306 & 1.26 \\
\hline & 757 & 458 & 1.87 \\
\hline & 1010 & 446 & 1.77 \\
\hline & 1212 & 387 & 1.57 \\
\hline & 1516 & 355 & 1.51 \\
\hline & 1771 & 342 & 1.47 \\
\hline & 2024 & 351 & 1.46 \\
\hline & 2277 & 386 & 1.46 \\
\hline & 2534 & 361 & 1.45 \\
\hline & 2789 & & 1.47 \\
\hline & 3043 & 357 & 1.48 \\
\hline & 3299 & 368 & 1.48 \\
\hline & 3554 & 396 & 1.50 \\
\hline & 3892 & 398 & 1.50 \\
\hline & 4231 & 397 & 1.52 \\
\hline & 4580 & & 1.51 \\
\hline
\end{tabular}




\begin{tabular}{|c|c|c|c|}
\hline USGT10-09 & 28 & 2 & 0.04 \\
\hline \multirow[t]{22}{*}{$\left(17.35^{\circ} \mathrm{N}, 18.25^{\circ} \mathrm{W}\right)$} & 49 & 5 & 0.69 \\
\hline & 89 & 151 & 1.52 \\
\hline & 109 & 170 & 1.51 \\
\hline & 135 & 241 & 1.57 \\
\hline & 185 & 275 & 1.64 \\
\hline & 221 & 329 & 1.68 \\
\hline & 285 & 381 & 1.78 \\
\hline & 361 & 468 & 1.93 \\
\hline & 665 & 553 & 2.17 \\
\hline & 797 & 569 & 2.22 \\
\hline & 965 & 565 & 2.15 \\
\hline & 1095 & 510 & 1.98 \\
\hline & 1200 & 485 & 1.91 \\
\hline & 1236 & 436 & 1.85 \\
\hline & 1385 & 427 & 1.73 \\
\hline & 1538 & 387 & 1.63 \\
\hline & 1787 & 378 & 1.54 \\
\hline & 1883 & 361 & 1.52 \\
\hline & 2088 & 370 & 1.49 \\
\hline & 2294 & 360 & 1.47 \\
\hline & 2585 & 370 & 1.48 \\
\hline & 2900 & 367 & 1.52 \\
\hline & 2999 & 389 & 1.54 \\
\hline USGT10-10 & 32 & 1 & 0.04 \\
\hline
\end{tabular}




\begin{tabular}{|c|c|c|c|}
\hline$\left(17.35^{\circ} \mathrm{N}, 20.82^{\circ} \mathrm{W}\right)$ & 51 & 7 & 1.15 \\
\hline & 85 & 148 & 1.53 \\
\hline & 101 & 197 & 1.56 \\
\hline & 141 & 226 & 1.53 \\
\hline & 188 & 228 & 1.62 \\
\hline & 237 & 242 & 1.65 \\
\hline & 293 & 274 & 1.77 \\
\hline & 424 & 279 & 1.97 \\
\hline & 503 & 489 & 2.08 \\
\hline & 607 & 538 & 2.31 \\
\hline & 806 & 519 & 2.28 \\
\hline & 973 & 597 & 2.14 \\
\hline & 1110 & 531 & 1.99 \\
\hline & 1261 & 483 & 1.86 \\
\hline & 1514 & 397 & 1.66 \\
\hline & 1770 & 416 & 1.55 \\
\hline & 2022 & 406 & 1.47 \\
\hline & 2277 & 380 & 1.46 \\
\hline & & & 1.47 \\
\hline & 2735 & 372 & 1.46 \\
\hline & 3042 & 381 & 1.51 \\
\hline & 3371 & 399 & 1.53 \\
\hline USGT10-11 & 30 & 2 & 0.05 \\
\hline$\left(17.35^{\circ} \mathrm{N}, 22.78^{\circ} \mathrm{W}\right)$ & 62 & 0 & 0.26 \\
\hline & 85 & 41 & 0.85 \\
\hline
\end{tabular}




\begin{tabular}{|c|c|c|c|}
\hline & 136 & 137 & 1.07 \\
\hline & 180 & 180 & 1.17 \\
\hline & 200 & 197 & 1.20 \\
\hline & 250 & 259 & 1.36 \\
\hline & 301 & 332 & 1.53 \\
\hline & 351 & 384 & 1.61 \\
\hline & 450 & 449 & 1.81 \\
\hline & 600 & 511 & 2.04 \\
\hline & 801 & & 2.12 \\
\hline & 964 & 503 & 2.04 \\
\hline & 1098 & 492 & 1.92 \\
\hline & 1248 & 423 & 1.78 \\
\hline & 1499 & 376 & 1.63 \\
\hline & 1748 & 349 & 1.52 \\
\hline & 1998 & 345 & 1.47 \\
\hline & 2248 & 350 & 1.44 \\
\hline & 2499 & 348 & 1.43 \\
\hline & 2748 & 345 & 1.43 \\
\hline & 2998 & 354 & 1.44 \\
\hline & 3198 & 361 & 1.45 \\
\hline & 3298 & 371 & 1.46 \\
\hline USGT10-12 & 38 & 4 & 0.02 \\
\hline$\left(17.35^{\circ} \mathrm{N}, 24.50^{\circ} \mathrm{W}\right)$ & 48 & 0 & 0.07 \\
\hline & 72 & 2 & 0.22 \\
\hline & 90 & 10 & 0.43 \\
\hline
\end{tabular}




\begin{tabular}{|c|c|c|c|}
\hline & 135 & 32 & 0.57 \\
\hline & 185 & 116 & 1.00 \\
\hline & 235 & 191 & 1.29 \\
\hline & 286 & 286 & 1.51 \\
\hline & 351 & 345 & 1.68 \\
\hline & 451 & 351 & 1.85 \\
\hline & 601 & 402 & 2.05 \\
\hline & 801 & 506 & 2.17 \\
\hline & 964 & 537 & 2.07 \\
\hline & 1099 & 507 & 1.90 \\
\hline & 1257 & 458 & 1.75 \\
\hline & 1499 & 415 & 1.62 \\
\hline & 1749 & 372 & 1.52 \\
\hline & 1999 & 366 & 1.48 \\
\hline & 2248 & 340 & 1.45 \\
\hline & 2499 & 348 & 1.45 \\
\hline & 2749 & 355 & 1.45 \\
\hline & 2998 & 360 & 1.44 \\
\hline & 3198 & 364 & 1.46 \\
\hline & 3498 & 379 & 1.47 \\
\hline USGT11-01 & 30 & 42 & 0.07 \\
\hline$\left(39.70^{\circ} \mathrm{N}, 69.80^{\circ} \mathrm{W}\right)$ & 59 & 45 & 0.16 \\
\hline & 91 & 126 & 0.68 \\
\hline & 111 & 173 & 0.90 \\
\hline & 135 & 197 & 1.01 \\
\hline
\end{tabular}




\begin{tabular}{|c|c|c|c|}
\hline & 186 & 305 & 1.39 \\
\hline & 236 & 298 & 1.35 \\
\hline & 286 & 366 & 1.52 \\
\hline & 326 & 363 & 1.56 \\
\hline & 421 & 329 & 1.47 \\
\hline & 476 & 333 & 1.40 \\
\hline & 526 & 316 & 1.34 \\
\hline & 600 & 297 & \\
\hline & 666 & 288 & 1.36 \\
\hline & 826 & 264 & 1.14 \\
\hline & 966 & 279 & 1.15 \\
\hline & 1076 & 289 & 1.18 \\
\hline & 1201 & 268 & 1.14 \\
\hline & 1351 & 273 & 1.11 \\
\hline & 1501 & 276 & 1.11 \\
\hline & 1652 & 268 & 1.12 \\
\hline & 1800 & 273 & 1.12 \\
\hline & 2001 & 268 & 1.13 \\
\hline & 2050 & 272 & 1.14 \\
\hline USGT11-02 & 35.3 & 20 & 0.04 \\
\hline$\left(39.35^{\circ} \mathrm{N}, 69.54^{\circ} \mathrm{W}\right)$ & 46.6 & 51 & 0.22 \\
\hline & 69.7 & 119 & 0.61 \\
\hline & 101.7 & 179 & 0.90 \\
\hline & 136.8 & 226 & 1.10 \\
\hline & 186.4 & 294 & 1.35 \\
\hline
\end{tabular}




\begin{tabular}{|c|c|c|c|}
\hline & 237.6 & 321 & 1.49 \\
\hline & 286.5 & 376 & 1.58 \\
\hline & 326.7 & 362 & 1.56 \\
\hline & 422 & 306 & 1.38 \\
\hline & 476.4 & 304 & 1.31 \\
\hline & 526.3 & 280 & 1.28 \\
\hline & 600.6 & 289 & 1.23 \\
\hline & 665.9 & 273 & 1.22 \\
\hline & 826.1 & 264 & 1.19 \\
\hline & 965.4 & 268 & 1.17 \\
\hline & 1200.6 & 273 & 1.17 \\
\hline & 1350.5 & 258 & 1.17 \\
\hline & 1501 & 256 & 1.17 \\
\hline & 1650.4 & 266 & 1.18 \\
\hline & 1800.3 & 272 & 1.19 \\
\hline & 2000.8 & 267 & 1.19 \\
\hline & 2199.7 & 275 & 1.20 \\
\hline & 2461.1 & 262 & 1.17 \\
\hline USGT11-03 & 28 & 2 & 0.02 \\
\hline$\left(38.69^{\circ} \mathrm{N}, 69.09^{\circ} \mathrm{W}\right)$ & 61 & 4 & 0.01 \\
\hline & 83 & 5 & 0.01 \\
\hline & 112 & 34 & 0.23 \\
\hline & 137 & 31 & 0.27 \\
\hline & 187 & 15 & 0.13 \\
\hline & 237 & 27 & 0.17 \\
\hline
\end{tabular}




\begin{tabular}{|c|c|c|c|}
\hline & 288 & 28 & 0.19 \\
\hline & 418 & 139 & 0.74 \\
\hline & 537 & 365 & 1.59 \\
\hline & 663 & 329 & 1.48 \\
\hline & 802 & 292 & 1.33 \\
\hline & 966 & 265 & 1.20 \\
\hline & 1078 & 272 & 1.18 \\
\hline & 1201 & 278 & 1.17 \\
\hline & 1353 & 275 & 1.19 \\
\hline & 1500 & 264 & 1.17 \\
\hline & 1801 & 271 & 1.17 \\
\hline & 2100 & 266 & 1.18 \\
\hline & 2400 & 275 & 1.19 \\
\hline & 2700 & 285 & 1.23 \\
\hline & 2899 & 274 & 1.16 \\
\hline & 3124 & 274 & 1.17 \\
\hline & 3274 & 276 & 1.18 \\
\hline USGT11-06 & 41 & 4 & 0.01 \\
\hline$\left(37.57^{\circ} \mathrm{N}, 68.45^{\circ} \mathrm{W}\right)$ & 66 & 2 & 0.00 \\
\hline & 90 & 11 & 0.00 \\
\hline & 112 & 0 & 0.00 \\
\hline & 142 & 23 & 0.12 \\
\hline & 166 & 63 & 0.34 \\
\hline & 237 & 105 & 0.59 \\
\hline & 286 & 136 & 0.73 \\
\hline
\end{tabular}




\begin{tabular}{|c|c|c|}
\hline 352 & 195 & 1.05 \\
\hline 422 & 309 & 1.32 \\
\hline 487 & 325 & 1.45 \\
\hline 602 & 355 & 1.53 \\
\hline 666 & 295 & 1.41 \\
\hline 750 & 298 & 1.33 \\
\hline 851 & 279 & 1.26 \\
\hline 966 & 277 & 1.22 \\
\hline 1085 & 256 & 1.20 \\
\hline 1201 & 254 & 1.19 \\
\hline 1302 & 266 & 1.19 \\
\hline 1401 & 267 & 1.18 \\
\hline 1501 & 250 & 1.18 \\
\hline 1600 & 253 & 1.18 \\
\hline 1699 & 262 & 1.18 \\
\hline 1799 & 253 & 1.18 \\
\hline 1951 & 263 & 1.15 \\
\hline 2100 & 268 & 1.17 \\
\hline 2400 & 259 & 1.22 \\
\hline 2699 & 267 & 1.22 \\
\hline 2999 & 293 & 1.25 \\
\hline 3299 & 291 & 1.23 \\
\hline 3598 & 293 & 1.25 \\
\hline 3798 & 309 & 1.28 \\
\hline 3997 & 319 & 1.29 \\
\hline
\end{tabular}




\begin{tabular}{|c|c|c|c|}
\hline & 4197 & 322 & 1.32 \\
\hline & 4432 & 336 & 1.37 \\
\hline & 4532 & 343 & 1.38 \\
\hline USGT11-08 & 32 & 2 & 0.00 \\
\hline$\left(35.42^{\circ} \mathrm{N}, 66.53^{\circ} \mathrm{W}\right)$ & 65 & 0 & 0.00 \\
\hline & 112 & 5 & 0.09 \\
\hline & 137 & 8 & 0.07 \\
\hline & 185 & 20 & 0.19 \\
\hline & 236 & 13 & 0.14 \\
\hline & 288 & 16 & 0.13 \\
\hline & 423 & 23 & 0.17 \\
\hline & 552 & 80 & 0.45 \\
\hline & 804 & 309 & 1.34 \\
\hline & 1003 & 312 & 1.36 \\
\hline & 1203 & 273 & 1.24 \\
\hline & 1500 & 286 & 1.17 \\
\hline & 1800 & 286 & 1.18 \\
\hline & 2101 & 288 & 1.19 \\
\hline & 2399 & 293 & 1.21 \\
\hline & 2699 & 292 & 1.23 \\
\hline & 2999 & 291 & 1.23 \\
\hline & 3299 & 316 & 1.24 \\
\hline & 3598 & 313 & 1.26 \\
\hline & 3898 & 325 & 1.28 \\
\hline & 4247 & 332 & 1.32 \\
\hline
\end{tabular}




\begin{tabular}{|c|c|c|c|}
\hline & 4572 & 355 & 1.36 \\
\hline & 4896 & 381 & 1.44 \\
\hline USGT11-10 & 40 & 5 & 0.03 \\
\hline \multirow[t]{22}{*}{$\left(31.75^{\circ} \mathrm{N}, 64.17^{\circ} \mathrm{W}\right)$} & 67 & 5 & 0.02 \\
\hline & 85 & 2 & 0.02 \\
\hline & 97 & 11 & 0.08 \\
\hline & 136 & 9 & 0.00 \\
\hline & 187 & 11 & 0.04 \\
\hline & 238 & 28 & 0.11 \\
\hline & 289 & 24 & 0.15 \\
\hline & 348 & 29 & 0.14 \\
\hline & 424 & 32 & 0.19 \\
\hline & 505 & 58 & 0.33 \\
\hline & 581 & 121 & 0.54 \\
\hline & 671 & 221 & 1.04 \\
\hline & 809 & 360 & 1.46 \\
\hline & 885 & 371 & 1.53 \\
\hline & 1087 & 332 & 1.41 \\
\hline & 1213 & 290 & 1.31 \\
\hline & 1366 & 289 & 1.23 \\
\hline & 1518 & 277 & 1.20 \\
\hline & 1670 & 260 & 1.19 \\
\hline & 1780 & 259 & 1.19 \\
\hline & 1821 & 254 & 1.19 \\
\hline & 1975 & 262 & 1.19 \\
\hline
\end{tabular}




\begin{tabular}{|c|c|c|c|}
\hline & 2100 & 267 & 1.21 \\
\hline & 2330 & 274 & 1.21 \\
\hline & 2533 & 273 & 1.21 \\
\hline & 2738 & 284 & 1.21 \\
\hline & 3043 & 288 & 1.22 \\
\hline & 3351 & 290 & 1.23 \\
\hline & 3657 & 300 & 1.26 \\
\hline & 3966 & 313 & 1.29 \\
\hline & 4273 & 334 & 1.33 \\
\hline & 4427 & 342 & 1.32 \\
\hline & 4520 & 340 & 1.34 \\
\hline & 4564 & 325 & 1.34 \\
\hline & 4613 & 328 & 1.34 \\
\hline USGT11-12 & 41 & 7 & 0.00 \\
\hline$\left(29.70^{\circ} \mathrm{N}, 56.82^{\circ} \mathrm{W}\right)$ & 66 & 0 & 0.00 \\
\hline & 100 & 2 & 0.00 \\
\hline & 137 & 4 & 0.04 \\
\hline & 188 & 9 & 0.16 \\
\hline & 238 & 18 & 0.17 \\
\hline & 288 & 25 & 0.19 \\
\hline & 351 & 30 & 0.26 \\
\hline & 421 & 69 & 0.33 \\
\hline & 504 & 124 & 0.56 \\
\hline & 667 & 187 & 1.00 \\
\hline & 753 & 288 & 1.31 \\
\hline
\end{tabular}




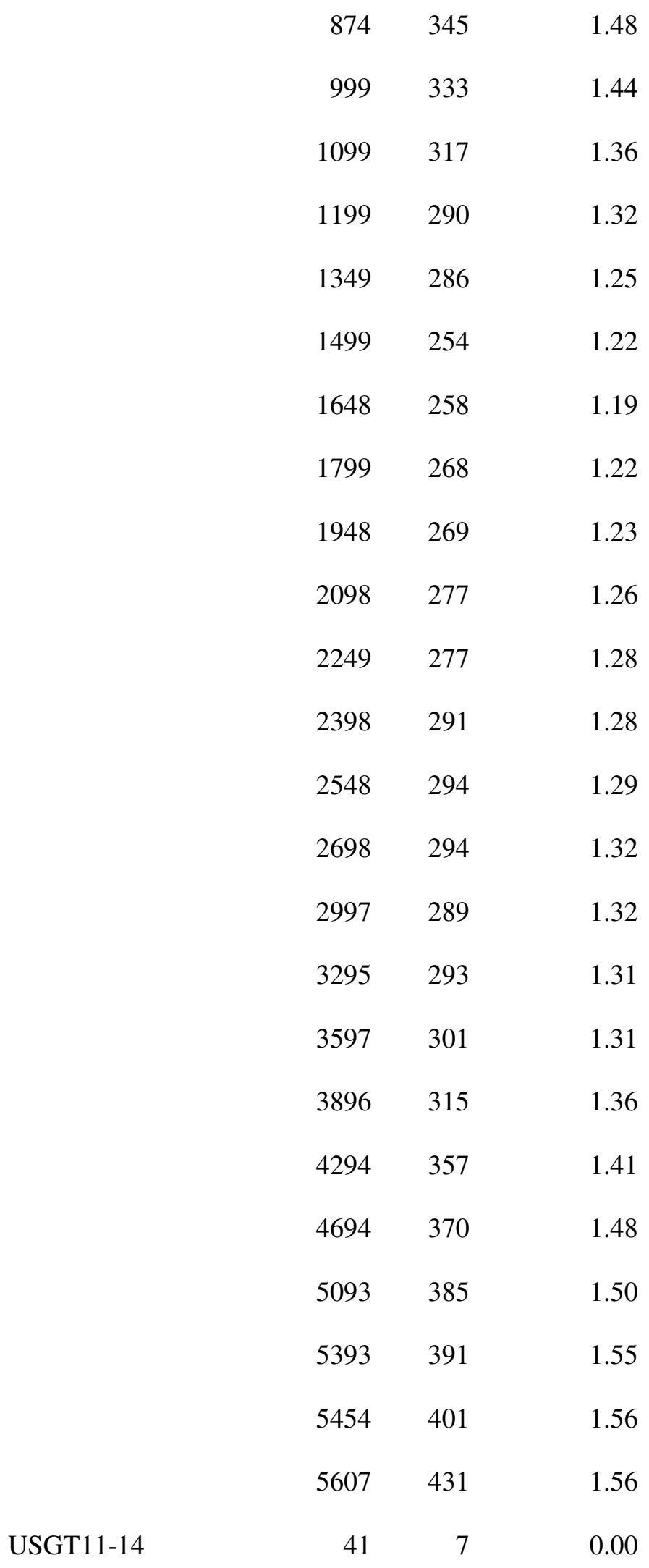




\begin{tabular}{|c|c|c|c|}
\hline$\left(27.58^{\circ} \mathrm{N}, 49.63^{\circ} \mathrm{W}\right)$ & 70 & 3 & 0.00 \\
\hline & 101 & 7 & 0.00 \\
\hline & 116 & 4 & 0.00 \\
\hline & 136 & 9 & 0.00 \\
\hline & 185 & 20 & 0.10 \\
\hline & 235 & 31 & 0.20 \\
\hline & 286 & 33 & 0.24 \\
\hline & 351 & 58 & 0.32 \\
\hline & 430 & 80 & 0.47 \\
\hline & 551 & 147 & 0.75 \\
\hline & 651 & 236 & 1.07 \\
\hline & 774 & 354 & 1.40 \\
\hline & 965 & 376 & 1.55 \\
\hline & 1199 & 346 & 1.38 \\
\hline & 1448 & 295 & 1.27 \\
\hline & 1799 & 292 & 1.27 \\
\hline & 2098 & 299 & 1.29 \\
\hline & 2398 & 324 & 1.32 \\
\hline & 2697 & 318 & 1.34 \\
\hline & 2997 & 347 & 1.34 \\
\hline & 3398 & 359 & 1.40 \\
\hline & 3797 & 366 & 1.42 \\
\hline & 4221 & 380 & 1.43 \\
\hline USGT11-16 & 41 & 0 & 0.00 \\
\hline$\left(26.14^{\circ} \mathrm{N}, 44.83^{\circ} \mathrm{W}\right)$ & 56 & 0 & 0.00 \\
\hline
\end{tabular}




\begin{tabular}{|c|c|c|}
\hline 92 & 5 & 0.00 \\
\hline 108 & 0 & 0.00 \\
\hline 136 & 5 & 0.00 \\
\hline 186 & 8 & 0.14 \\
\hline 235 & 16 & 0.23 \\
\hline 285 & 35 & 0.27 \\
\hline 338 & 53 & 0.34 \\
\hline 421 & 89 & 0.57 \\
\hline 512 & 147 & 0.75 \\
\hline 602 & 198 & 1.04 \\
\hline 799 & 378 & 1.58 \\
\hline 965 & 354 & \\
\hline 1199 & 276 & \\
\hline 1500 & 275 & 1.29 \\
\hline 1650 & 290 & 1.29 \\
\hline 1798 & 283 & 1.26 \\
\hline 1949 & 291 & 1.29 \\
\hline 2099 & 286 & 1.30 \\
\hline 2248 & 309 & 1.31 \\
\hline 2399 & 314 & 1.33 \\
\hline 2698 & 326 & 1.36 \\
\hline 2999 & 306 & 1.38 \\
\hline 3252 & 306 & 1.37 \\
\hline 3275 & 328 & 1.38 \\
\hline 3330 & 322 & 1.39 \\
\hline
\end{tabular}




\begin{tabular}{|c|c|c|c|}
\hline & 3342 & 267 & 1.39 \\
\hline & 3420 & 322 & 1.39 \\
\hline & 3587 & 329 & 1.40 \\
\hline USGT11-18 & 40 & 5 & 0.01 \\
\hline$\left(24.15^{\circ} \mathrm{N}, 40.22^{\circ} \mathrm{W}\right)$ & 67 & 3 & 0.00 \\
\hline & 76 & 8 & 0.00 \\
\hline & 111 & 5 & 0.00 \\
\hline & 137 & 8 & 0.01 \\
\hline & 186 & 21 & 0.10 \\
\hline & 236 & 21 & 0.21 \\
\hline & 286 & 51 & 0.32 \\
\hline & 352 & 73 & 0.47 \\
\hline & 421 & 137 & 0.68 \\
\hline & 511 & 196 & 0.89 \\
\hline & 601 & 253 & 1.10 \\
\hline & 776 & 286 & 1.38 \\
\hline & 966 & 401 & 1.61 \\
\hline & 1151 & 375 & 1.53 \\
\hline & 1325 & 338 & 1.41 \\
\hline & 1501 & 332 & 1.36 \\
\hline & 1800 & 314 & 1.34 \\
\hline & 2098 & 323 & 1.37 \\
\hline & 2550 & 345 & 1.41 \\
\hline & 3000 & 362 & 1.43 \\
\hline & 3399 & 377 & 1.45 \\
\hline
\end{tabular}




\begin{tabular}{|c|c|c|c|}
\hline & 3799 & 375 & 1.47 \\
\hline & 4297 & 391 & 1.49 \\
\hline USGT11-20 & 41 & -2 & 0.00 \\
\hline \multirow[t]{22}{*}{$\left(22.33^{\circ} \mathrm{N}, 35.87^{\circ} \mathrm{W}\right)$} & 66 & 0 & 0.00 \\
\hline & 76 & -1 & 0.00 \\
\hline & 106 & 2 & 0.05 \\
\hline & 137 & 23 & 0.18 \\
\hline & 187 & 13 & 0.31 \\
\hline & 236 & 41 & 0.53 \\
\hline & 301 & 82 & 0.61 \\
\hline & 376 & 141 & 0.86 \\
\hline & 441 & 168 & 0.95 \\
\hline & 501 & 209 & 1.06 \\
\hline & 601 & 287 & 1.37 \\
\hline & 700 & 350 & 1.48 \\
\hline & 810 & 397 & 1.69 \\
\hline & 926 & 409 & 1.79 \\
\hline & 1061 & 388 & 1.73 \\
\hline & 1199 & 357 & 1.61 \\
\hline & 1349 & 314 & 1.48 \\
\hline & 1500 & 303 & 1.45 \\
\hline & 1626 & 297 & 1.41 \\
\hline & 1750 & 306 & 1.41 \\
\hline & 1897 & 298 & 1.37 \\
\hline & 2099 & 299 & 1.37 \\
\hline
\end{tabular}




\begin{tabular}{|c|c|c|c|}
\hline & 2298 & 296 & 1.38 \\
\hline & 2497 & 304 & 1.39 \\
\hline & 2698 & 313 & 1.40 \\
\hline & 3096 & 340 & 1.42 \\
\hline & 3496 & 358 & 1.44 \\
\hline & 3896 & 360 & 1.46 \\
\hline & 4295 & 362 & 1.47 \\
\hline & 4696 & 362 & 1.49 \\
\hline & 4892 & 368 & 1.48 \\
\hline & 5096 & 370 & 1.49 \\
\hline & 5243 & 374 & 1.48 \\
\hline & 5384 & 363 & 1.49 \\
\hline & 5792 & 367 & 1.48 \\
\hline USGT11-22 & 51 & 2 & 0.00 \\
\hline$\left(19.43^{\circ} \mathrm{N}, 29.38^{\circ} \mathrm{W}\right)$ & 81 & 0 & 0.00 \\
\hline & 95 & 1 & 0.02 \\
\hline & 125 & 12 & 0.38 \\
\hline & 186 & 119 & 0.86 \\
\hline & 236 & 154 & 0.93 \\
\hline & 286 & 191 & 1.00 \\
\hline & 391 & 266 & 1.20 \\
\hline & 552 & 403 & 1.65 \\
\hline & 665 & 433 & 1.80 \\
\hline & 901 & 508 & 2.02 \\
\hline & 1200 & 416 & 1.75 \\
\hline
\end{tabular}




\begin{tabular}{|c|c|c|c|}
\hline & 1498 & 365 & 1.49 \\
\hline & 1798 & 336 & 1.41 \\
\hline & 2098 & 328 & 1.40 \\
\hline & 2397 & 327 & 1.40 \\
\hline & 2697 & 342 & 1.41 \\
\hline & 2997 & 355 & 1.43 \\
\hline & 3296 & 412 & 1.45 \\
\hline & 3595 & 401 & 1.47 \\
\hline & 3895 & 388 & 1.48 \\
\hline & 4194 & 392 & 1.49 \\
\hline & 4595 & 400 & 1.49 \\
\hline & 4979 & 396 & 1.50 \\
\hline USGT11-24 & 40 & 10 & 0.00 \\
\hline$\left(17.40^{\circ} \mathrm{N}, 24.50^{\circ} \mathrm{W}\right)$ & 51 & 4 & 0.00 \\
\hline & 71 & 4 & 0.13 \\
\hline & 91 & 11 & 0.47 \\
\hline & 136 & 76 & 0.75 \\
\hline & 187 & 149 & 1.04 \\
\hline & 237 & 251 & 1.47 \\
\hline & 288 & 316 & 1.60 \\
\hline & 354 & 383 & 1.68 \\
\hline & 454 & 443 & 1.87 \\
\hline & 605 & 487 & 1.98 \\
\hline & 808 & 532 & 2.11 \\
\hline & 973 & 514 & 2.03 \\
\hline
\end{tabular}




$\begin{array}{lll}1109 & 474 & 1.93 \\ 1269 & 438 & 1.72 \\ 1515 & 394 & 1.65 \\ 1768 & 347 & 1.47 \\ 2022 & 334 & 1.43 \\ 2276 & 350 & 1.42 \\ 2531 & 340 & 1.41 \\ 3040 & 337 & 1.40 \\ 3245 & 364 & 1.41 \\ 3346 & 354 & 1.42 \\ 3572 & 380 & 1.45\end{array}$


Table Parameters used in the model along with the model results compared with measured data at the 2. North Atlantic and the North Pacific

Modele

d

\begin{tabular}{|c|c|c|c|c|c|c|c|c|c|c|}
\hline & & & & $\begin{array}{c}{[\mathrm{Cd}]^{0}} \\
/[\mathrm{P}]^{0}\end{array}$ & & & & Model & Model & $\mathrm{Cd}: \mathrm{PO} 4$ \\
\hline & $\begin{array}{c}\text { Depth } \\
(\mathrm{m})\end{array}$ & $t(y r)$ & $\begin{array}{c}{[\mathrm{P}]^{0}} \\
(\mu \mathrm{M})\end{array}$ & $\begin{array}{c}(\mathrm{pM} / \mu \\
\mathrm{M})\end{array}$ & $\begin{array}{l}{[\mathrm{Cd}]^{0}} \\
(\mathrm{pM})\end{array}$ & $\begin{array}{l}1 / k_{p} \\
(y r)\end{array}$ & $\begin{array}{c}1 / k_{\mathrm{cd}} \\
(\mathrm{yr})\end{array}$ & $\begin{array}{c}{[\mathrm{PO} 4]} \\
(\mu \mathrm{M})\end{array}$ & $\begin{array}{l}{[\mathrm{Cd}]} \\
(\mathrm{pM})\end{array}$ & $\begin{array}{c}(\mathrm{pM} / \mu \\
\mathrm{M})\end{array}$ \\
\hline Model & 100 & 0.2 & 0.01 & 1.0 & 1 & 224 & 224 & 0.08 & 4 & 55 \\
\hline N Atlantic & 150 & 0.3 & 0.03 & 1.2 & 3 & 772 & 772 & 0.07 & 6 & 92 \\
\hline & 200 & 0.5 & 0.05 & 1.3 & 6 & 1638 & 1638 & 0.08 & 9 & 121 \\
\hline & 250 & 0.8 & 0.06 & 1.5 & 9 & 2667 & 2667 & 0.09 & 13 & 142 \\
\hline & 300 & 1 & 0.08 & 1.6 & 13 & 3727 & 3727 & 0.11 & 17 & 159 \\
\hline & 350 & 4 & 0.10 & 1.8 & 17 & 4751 & 4751 & 0.18 & 31 & 172 \\
\hline & 400 & 8 & 0.12 & 1.9 & 22 & 5721 & 5721 & 0.25 & 47 & 184 \\
\hline & 450 & 10 & 0.13 & 2.1 & 28 & 6634 & 6634 & 0.28 & 55 & 196 \\
\hline & 500 & 12 & 0.15 & 2.2 & 33 & 7500 & 7500 & 0.31 & 64 & 206 \\
\hline & 600 & 17 & 0.25 & 2.5 & 63 & 9117 & 9117 & 0.43 & 99 & 230 \\
\hline & 750 & 80 & 0.40 & 3.0 & 120 & 11347 & 11347 & 1.10 & 262 & 238 \\
\hline & 950 & 125 & 0.60 & 2.9 & 172 & 14098 & 14098 & 1.48 & 353 & 239 \\
\hline & 1150 & 125 & 0.60 & 2.7 & 165 & 16694 & 16694 & 1.34 & 318 & 237 \\
\hline & 1400 & 125 & 0.60 & 2.6 & 155 & 19798 & 19798 & 1.23 & 285 & 233 \\
\hline & 1700 & 130 & 0.61 & 2.4 & 147 & 23378 & 23378 & 1.17 & 262 & 225 \\
\hline & 2000 & 150 & 0.63 & 2.2 & 138 & 26841 & 26841 & 1.18 & 254 & 215 \\
\hline & 2500 & 180 & 0.65 & 2.3 & 152 & 32418 & 32418 & 1.20 & 267 & 222 \\
\hline & 3000 & 200 & 0.68 & 2.5 & 167 & 37808 & 37808 & 1.20 & 277 & 230 \\
\hline
\end{tabular}




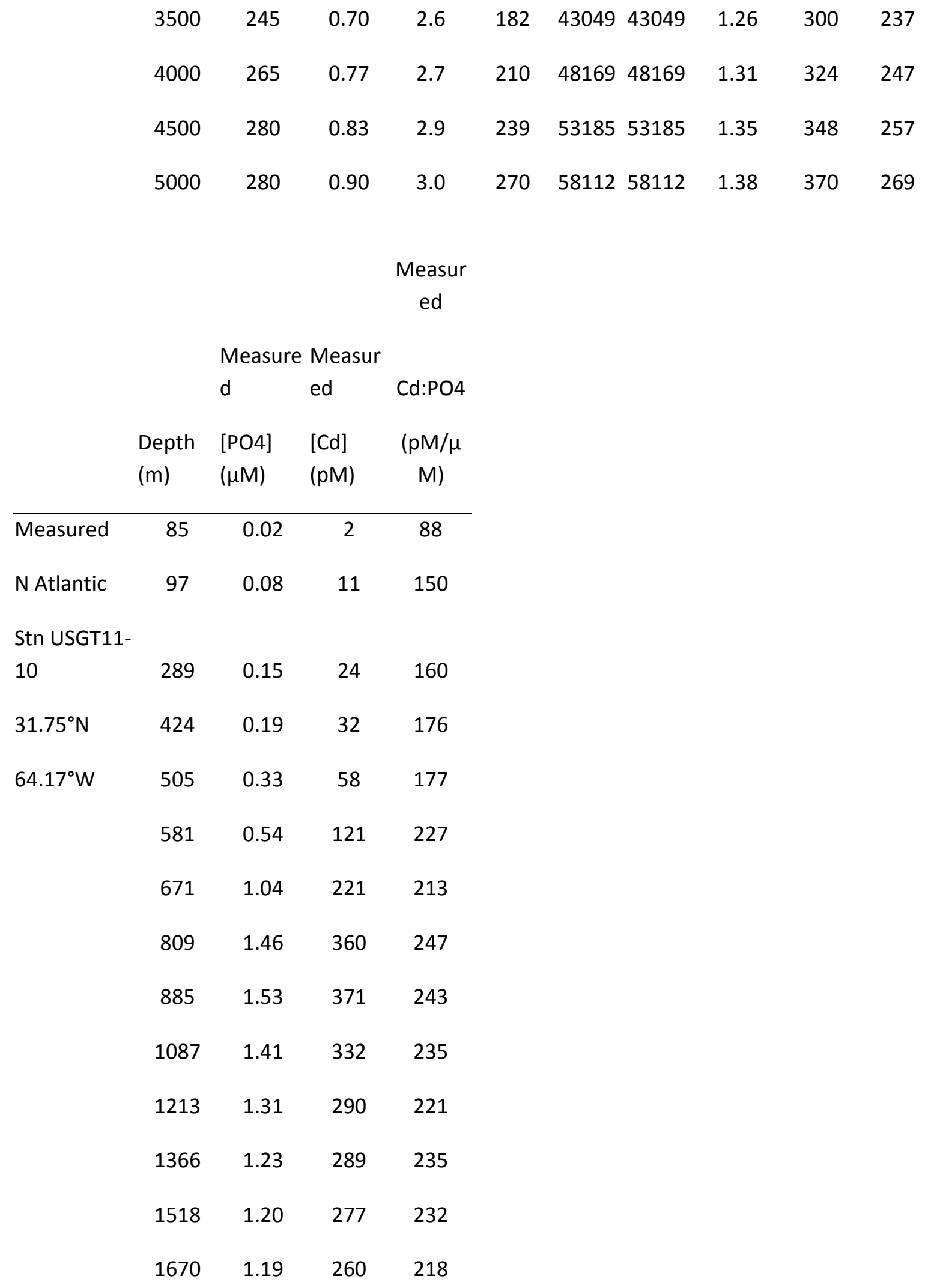




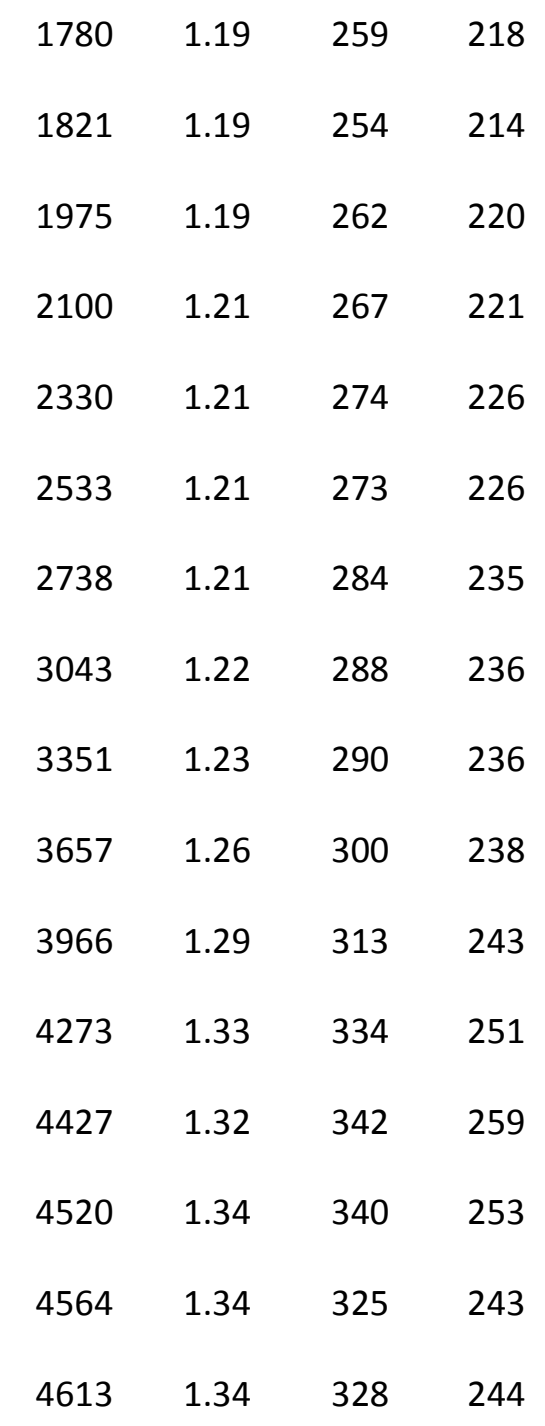

Modele

d

$[\mathrm{Cd}]^{0}$

$/[\mathrm{P}]^{0} \quad$ Model Model Cd:PO4

$\begin{array}{llllllll}\text { Depth } \quad[\mathrm{P}]^{0} & (\mathrm{pM} / \mu & {[\mathrm{Cd}]^{0}} & 1 / \mathrm{k}_{\mathrm{p}} & 1 / \mathrm{k}_{\mathrm{cd}} & {[\mathrm{PO} 4]} & {[\mathrm{Cd}]} & (\mathrm{pM} / \mu\end{array}$ $\begin{array}{llllllllll}(\mathrm{m}) & \mathrm{t}(\mathrm{yr}) & (\mu \mathrm{M}) & \mathrm{M}) & (\mathrm{pM}) & (\mathrm{yr}) & (\mathrm{yr}) & (\mu \mathrm{M}) & (\mathrm{pM}) & \mathrm{M})\end{array}$

\begin{tabular}{lllllllllll}
\hline Model & 100 & 0.2 & 0.01 & 1.0 & 1 & 224 & 224 & 0.08 & 5 & 67
\end{tabular}

$\begin{array}{lllllllllll}\text { N Pacific } & 150 & 0.3 & 0.07 & 1.2 & 8 & 772 & 772 & 0.11 & 12 & 113\end{array}$

$\begin{array}{llllllllll}200 & 10 & 0.13 & 1.3 & 17 & 1638 & 1638 & 0.74 & 115 & 155\end{array}$




\begin{tabular}{|c|c|c|c|c|c|c|c|c|c|}
\hline 250 & 20 & 0.19 & 1.5 & 28 & 2667 & 2667 & 0.94 & 182 & 194 \\
\hline 300 & 38 & 0.26 & 1.6 & 41 & 3727 & 3727 & 1.27 & 285 & 225 \\
\hline 350 & 58 & 0.32 & 1.8 & 56 & 4751 & 4751 & 1.53 & 379 & 248 \\
\hline 400 & 80 & 0.38 & 1.9 & 73 & 5721 & 5721 & 1.76 & 467 & 265 \\
\hline 450 & 105 & 0.44 & 2.1 & 91 & 6634 & 6634 & 2.00 & 557 & 278 \\
\hline 500 & 130 & 0.50 & 2.2 & 112 & 7500 & 7500 & 2.21 & 637 & 288 \\
\hline 600 & 195 & 0.57 & 2.5 & 144 & 9117 & 9117 & 2.67 & 815 & 305 \\
\hline 750 & 280 & 0.67 & 3.0 & 200 & 11347 & 11347 & 3.09 & 994 & 322 \\
\hline 950 & 360 & 0.80 & 3.0 & 240 & 14098 & 14098 & 3.30 & 1074 & 325 \\
\hline 1150 & 392 & 0.81 & 3.0 & 244 & 16694 & 16694 & 3.12 & 1019 & 327 \\
\hline 1400 & 440 & 0.83 & 3.0 & 250 & 19798 & 19798 & 3.01 & 987 & 327 \\
\hline 1700 & 480 & 0.86 & 3.0 & 257 & 23378 & 23378 & 2.87 & 940 & 327 \\
\hline 2000 & 530 & 0.88 & 3.0 & 263 & 26841 & 26841 & 2.82 & 921 & 327 \\
\hline 2500 & 620 & 0.91 & 3.0 & 274 & 32418 & 32418 & 2.79 & 912 & 327 \\
\hline 3000 & 680 & 0.95 & 3.0 & 286 & 37808 & 37808 & 2.72 & 886 & 326 \\
\hline 3500 & 730 & 0.99 & 3.0 & 297 & 43049 & 43049 & 2.65 & 863 & 325 \\
\hline 4000 & 780 & 1.03 & 3.0 & 308 & 48169 & 48169 & 2.62 & 849 & 324 \\
\hline 4500 & 810 & 1.06 & 3.0 & 319 & 53185 & 53185 & 2.56 & 828 & 324 \\
\hline 5000 & 820 & 1.10 & 3.0 & 330 & 58112 & 58112 & 2.49 & 802 & 323 \\
\hline
\end{tabular}

Measure Measur

d ed $\quad \mathrm{Cd}: \mathrm{PO} 4$

Depth [PO4] [Cd] $\quad(\mathrm{pM} / \mu$

$(\mathrm{m}) \quad(\mu \mathrm{M}) \quad(\mathrm{pM}) \quad \mathrm{M})$ 


$\begin{array}{lrrrr}\text { Measured } & 0 & 0.06 & 2 & 33 \\ \text { N Pacific } & 75 & 0.18 & 5 & 25 \\ 32.80^{\circ} \mathrm{N} & 185 & 0.81 & 170 & 210 \\ 144.90^{\circ} \mathrm{W} & 375 & 1.56 & 490 & 314 \\ \text { (Bruland, } & & & & \\ \text { 1979) } & 595 & 2.87 & 830 & 289 \\ & 780 & 3.27 & 970 & 297 \\ & 985 & 3.33 & 1040 & 312 \\ & 1505 & 2.95 & 1000 & 339 \\ & 2025 & 2.80 & 910 & 325 \\ & 2575 & 2.77 & 910 & 329 \\ & 3055 & 2.71 & 840 & 310 \\ & 4675 & 2.43 & 810 & 333\end{array}$




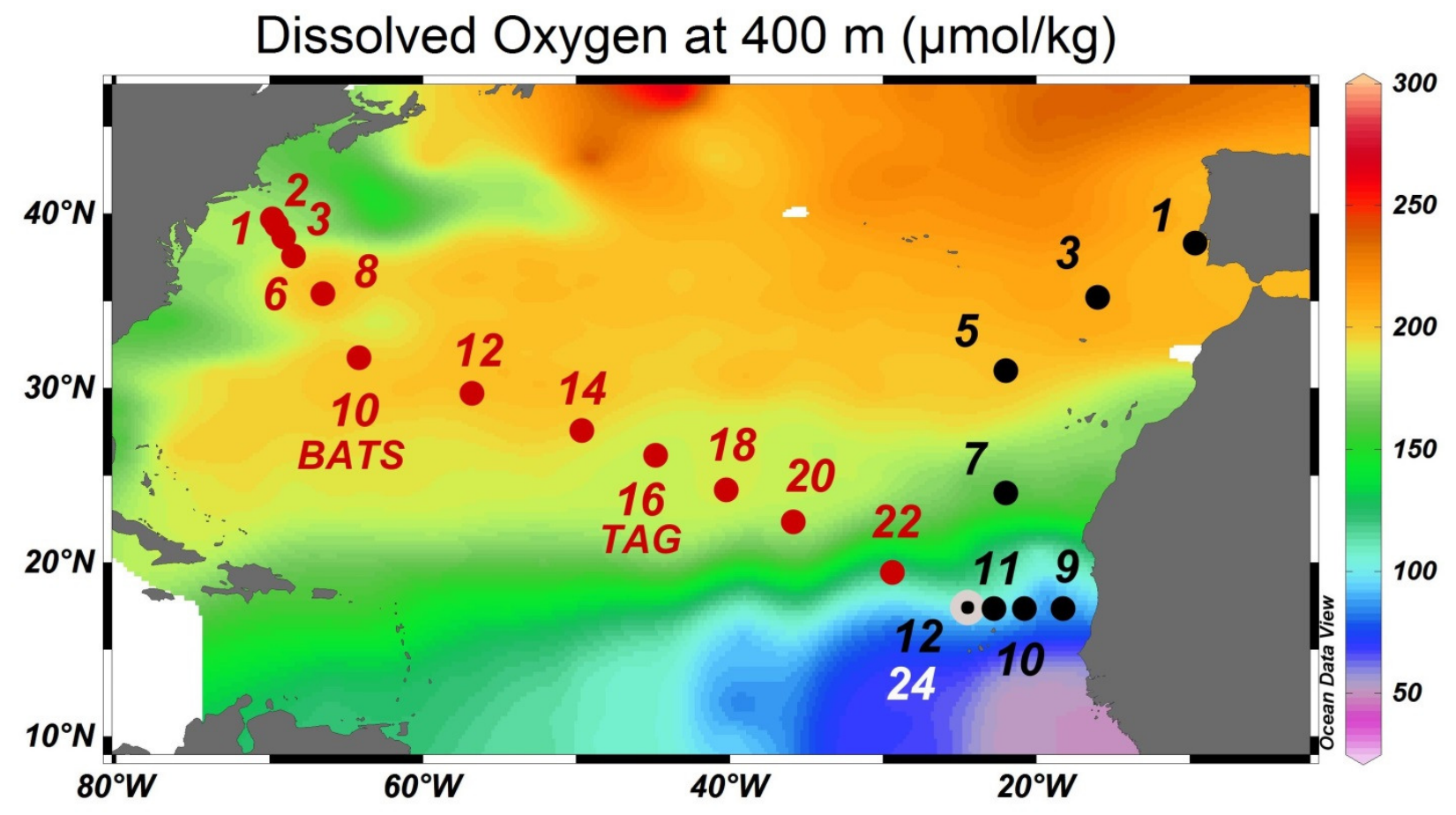

Figure 1a

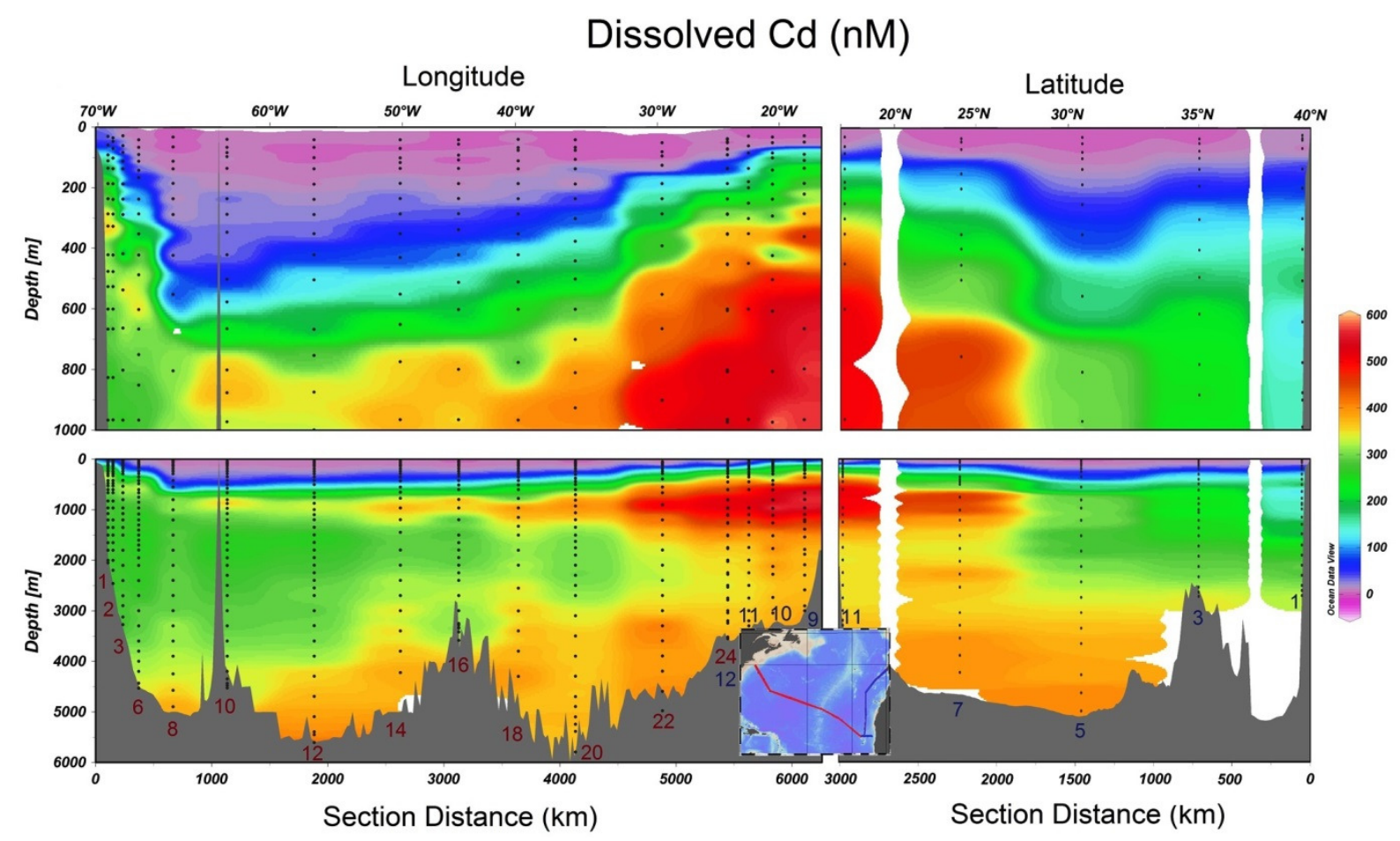

Figure 1b 


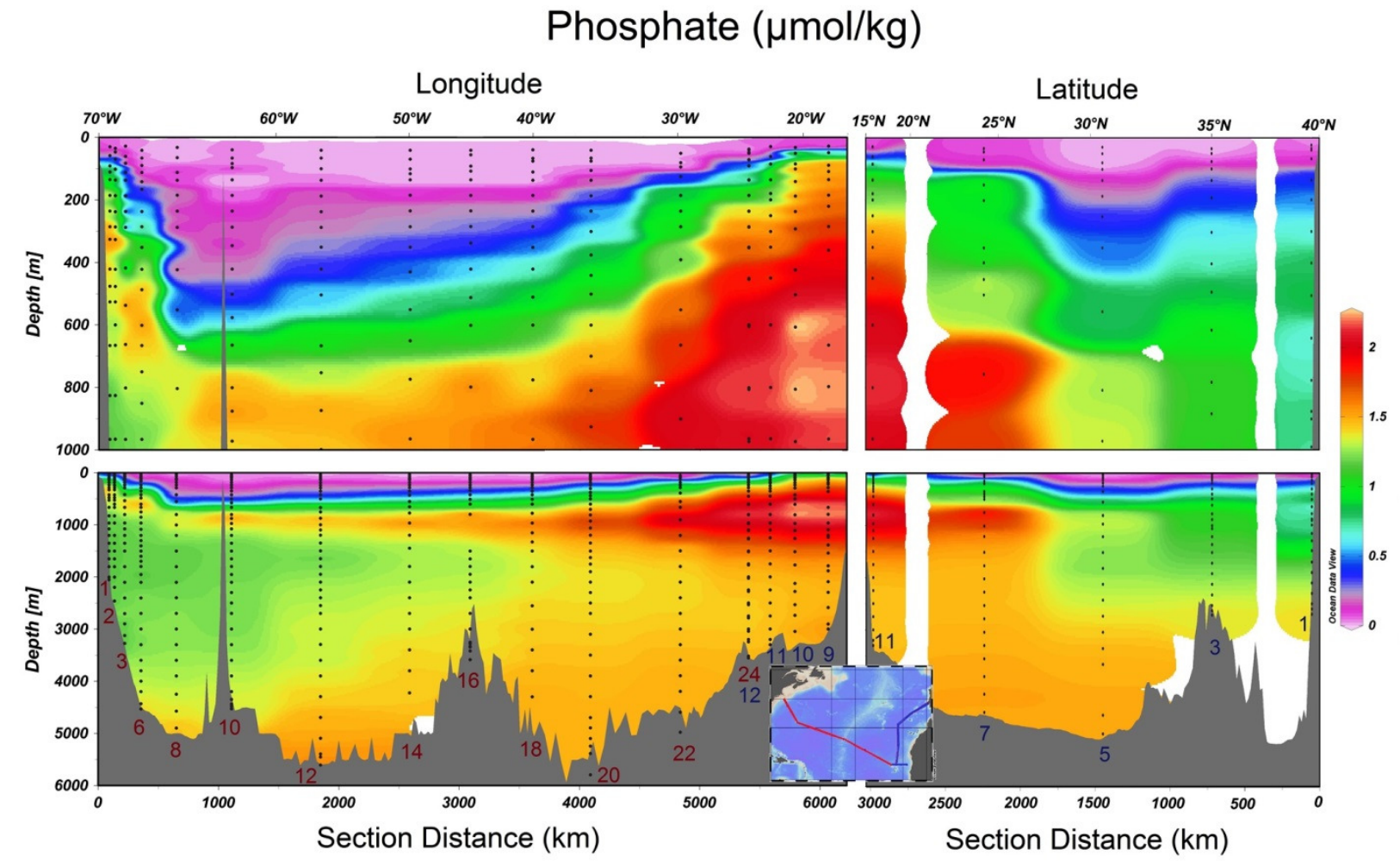

Figure 1c

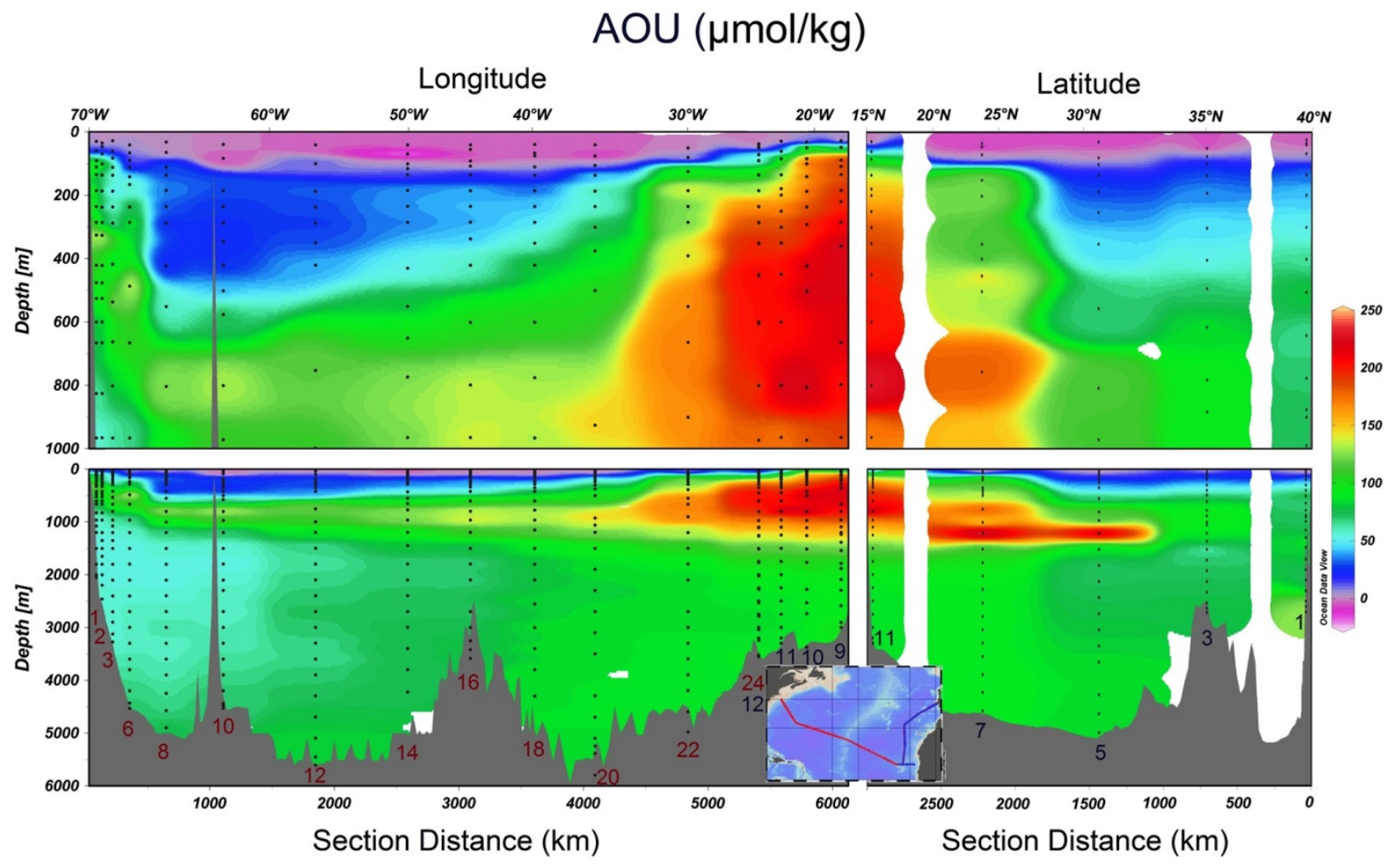




\section{Figure 1d}

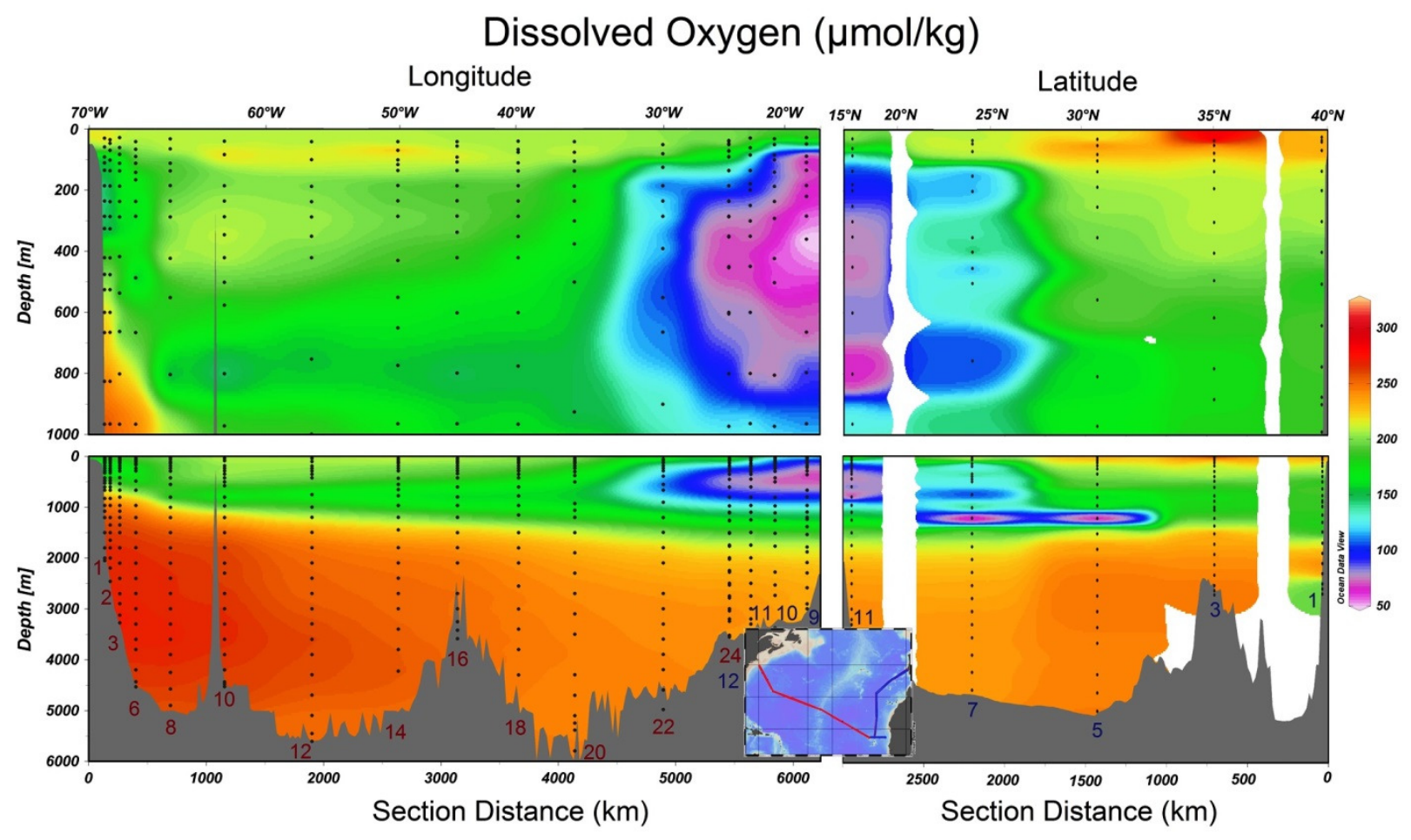

Figure 1e 


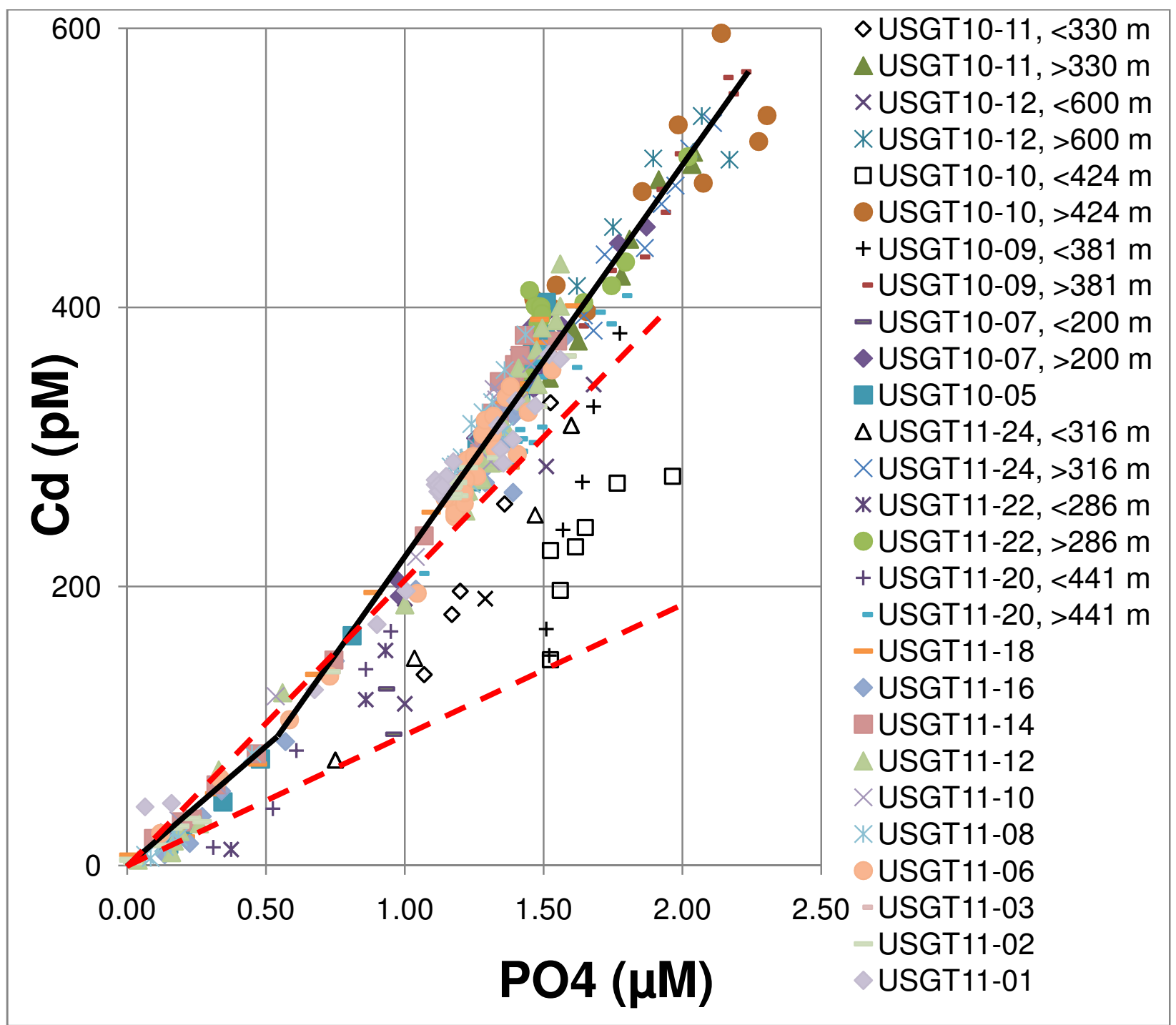

Figure 2 


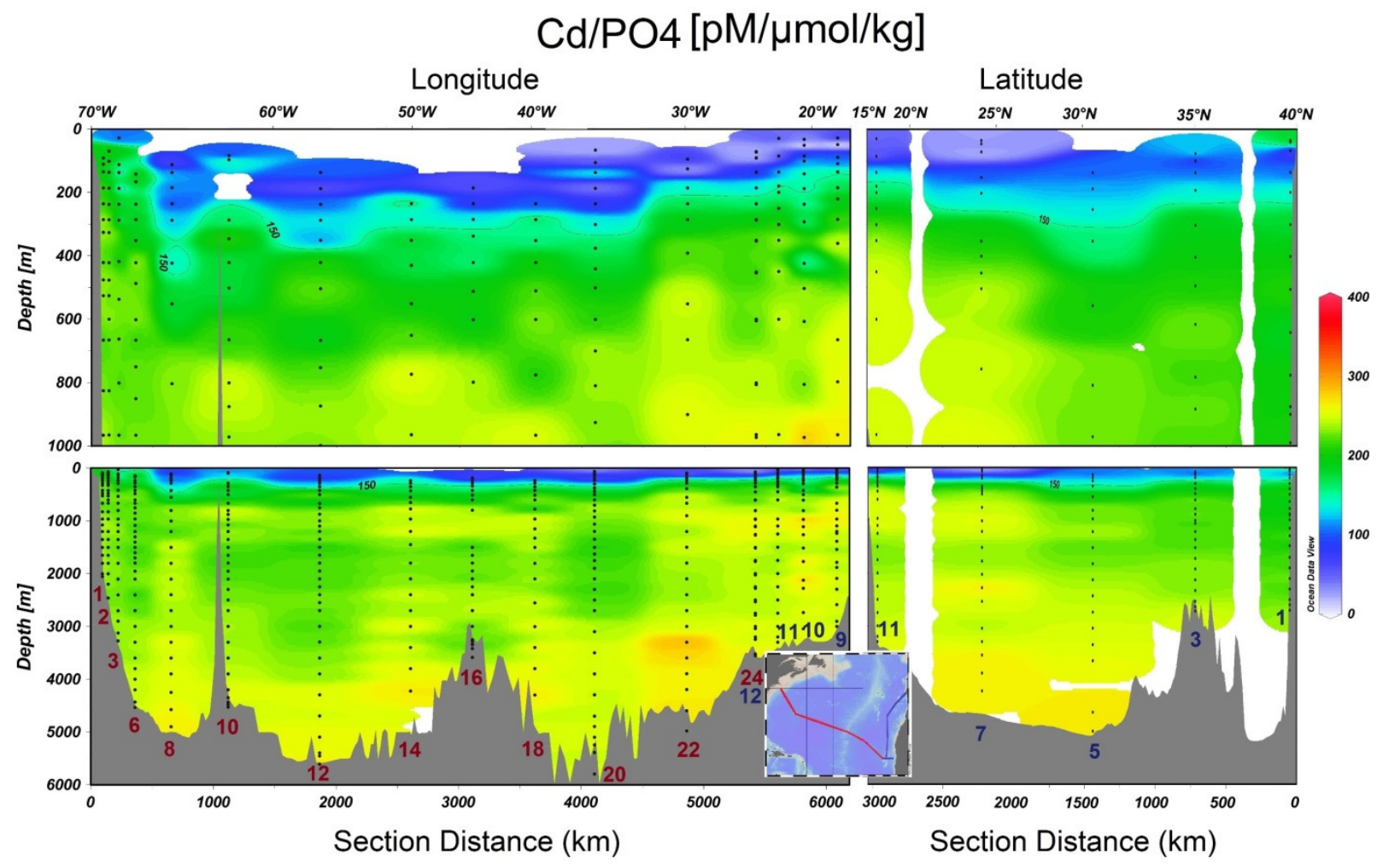

Figure 3 


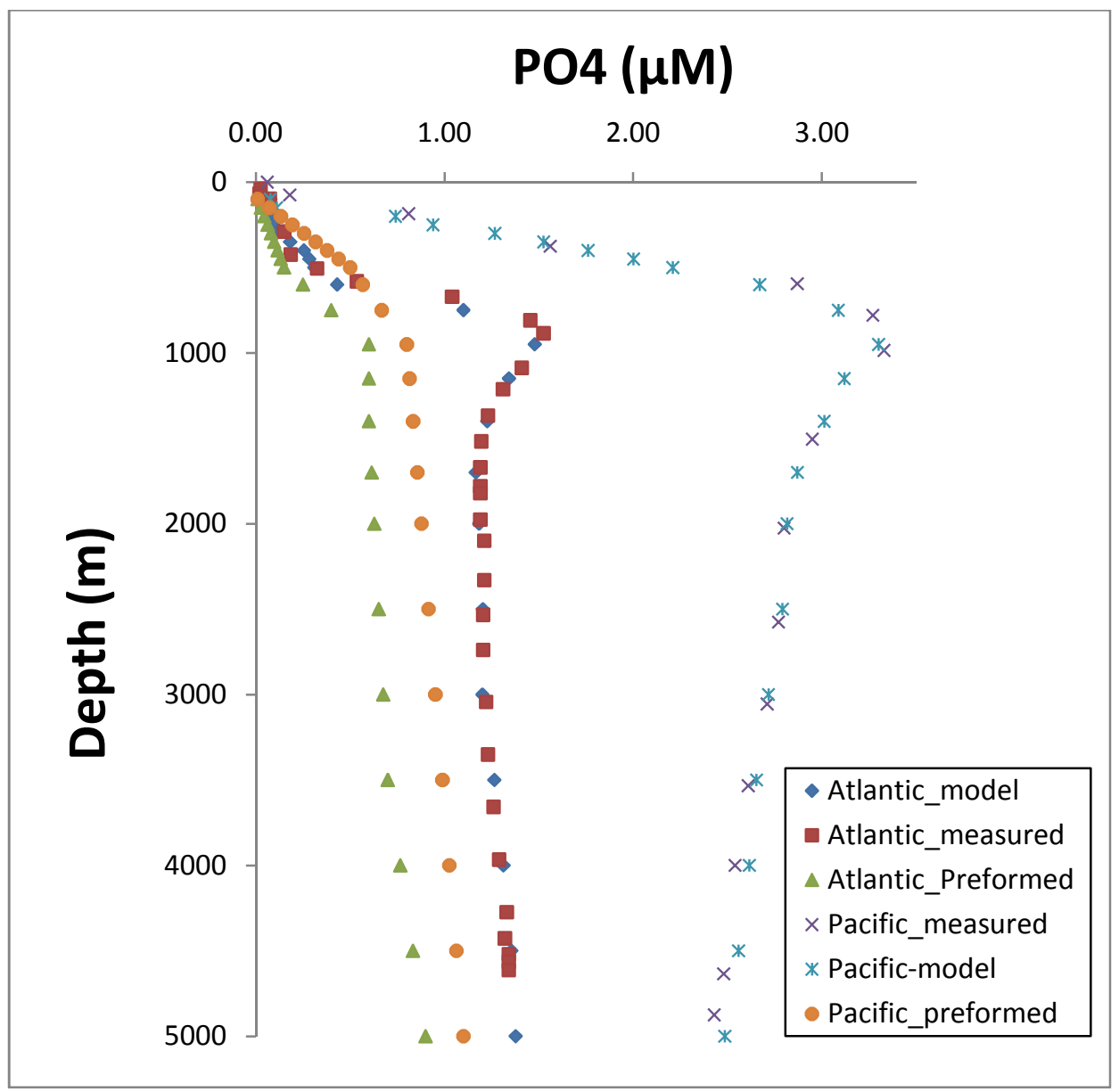

Figure 4a 


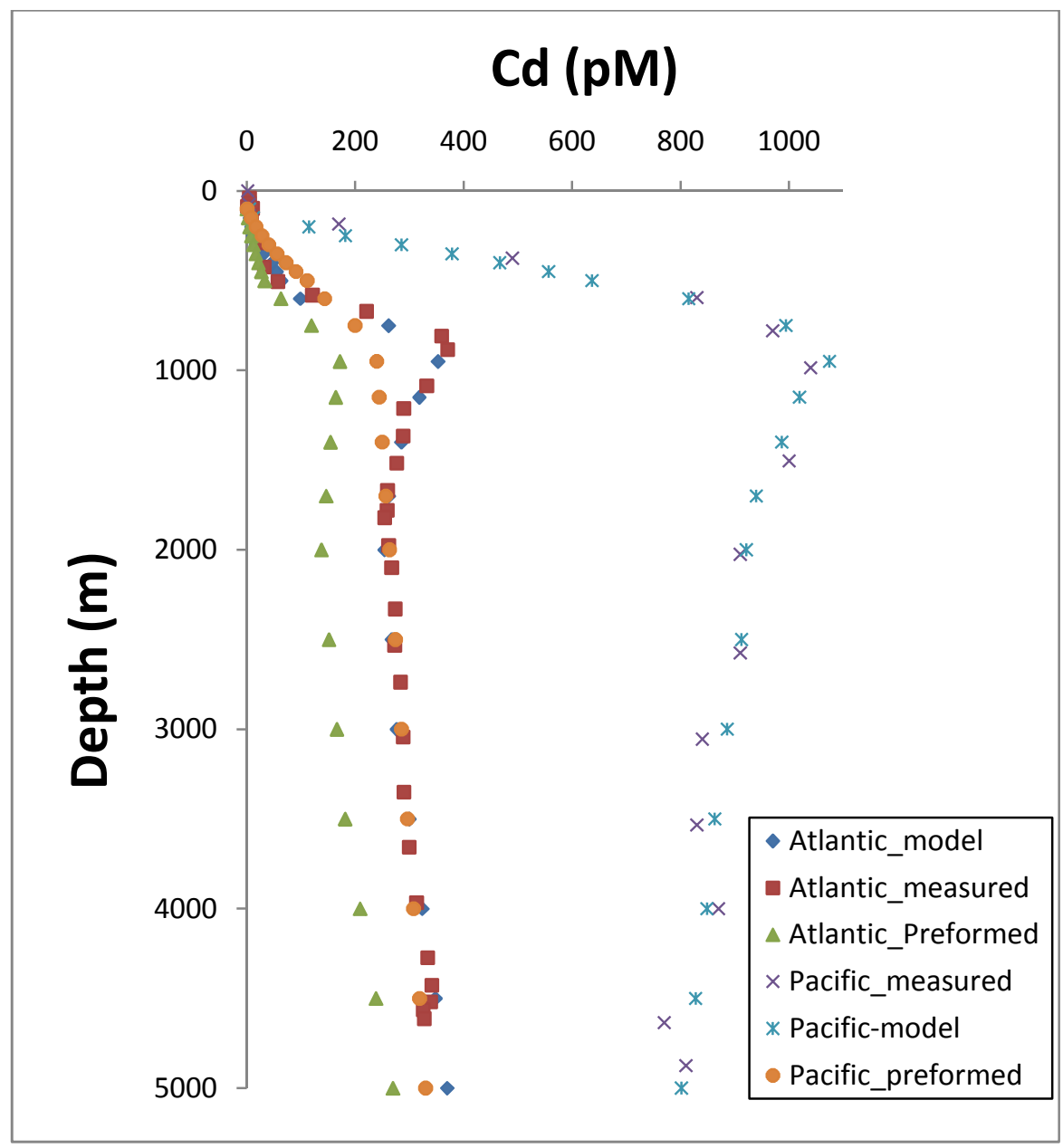

Figure 4b 


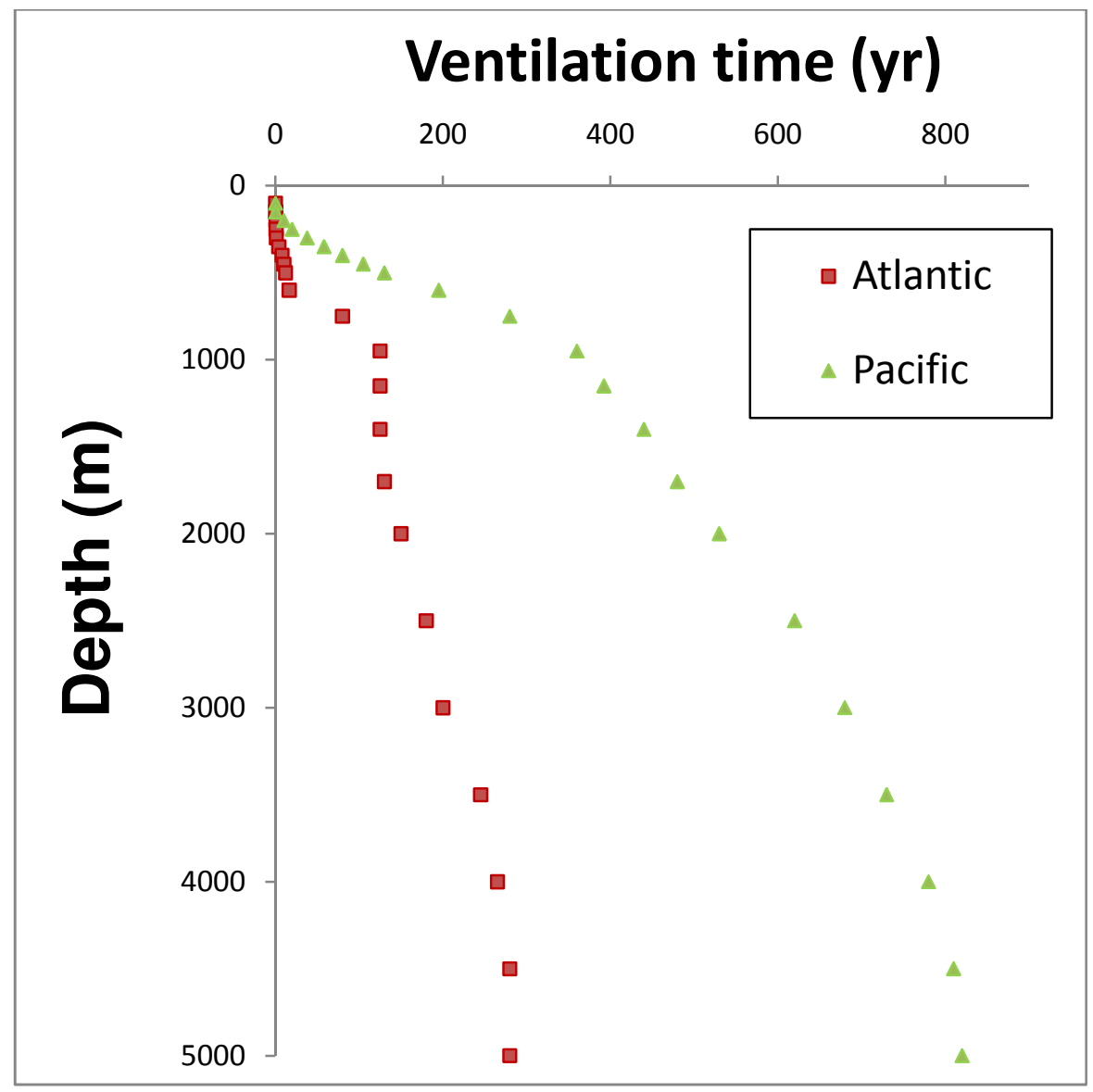

Figure 4c 


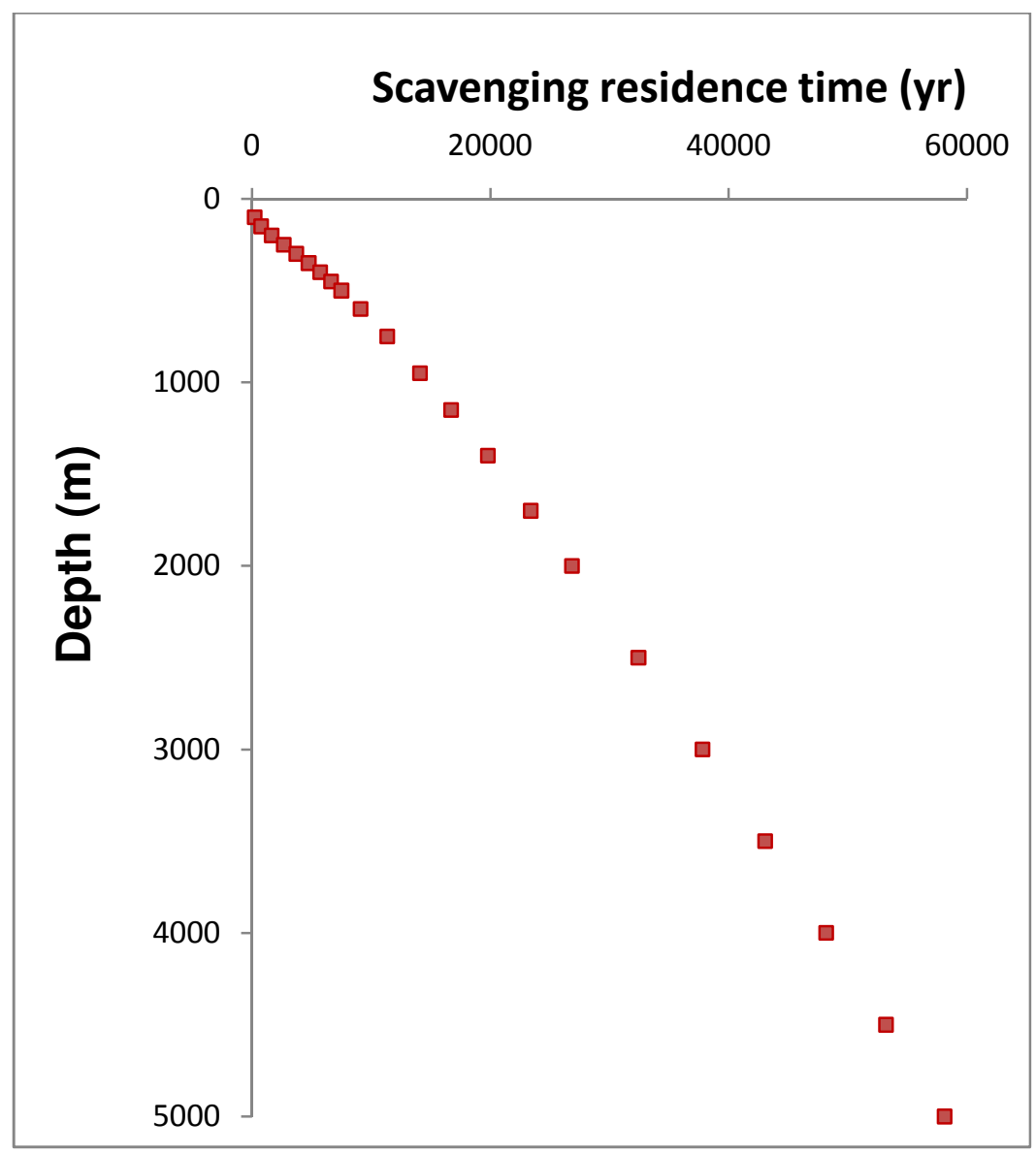

Figure 4d 


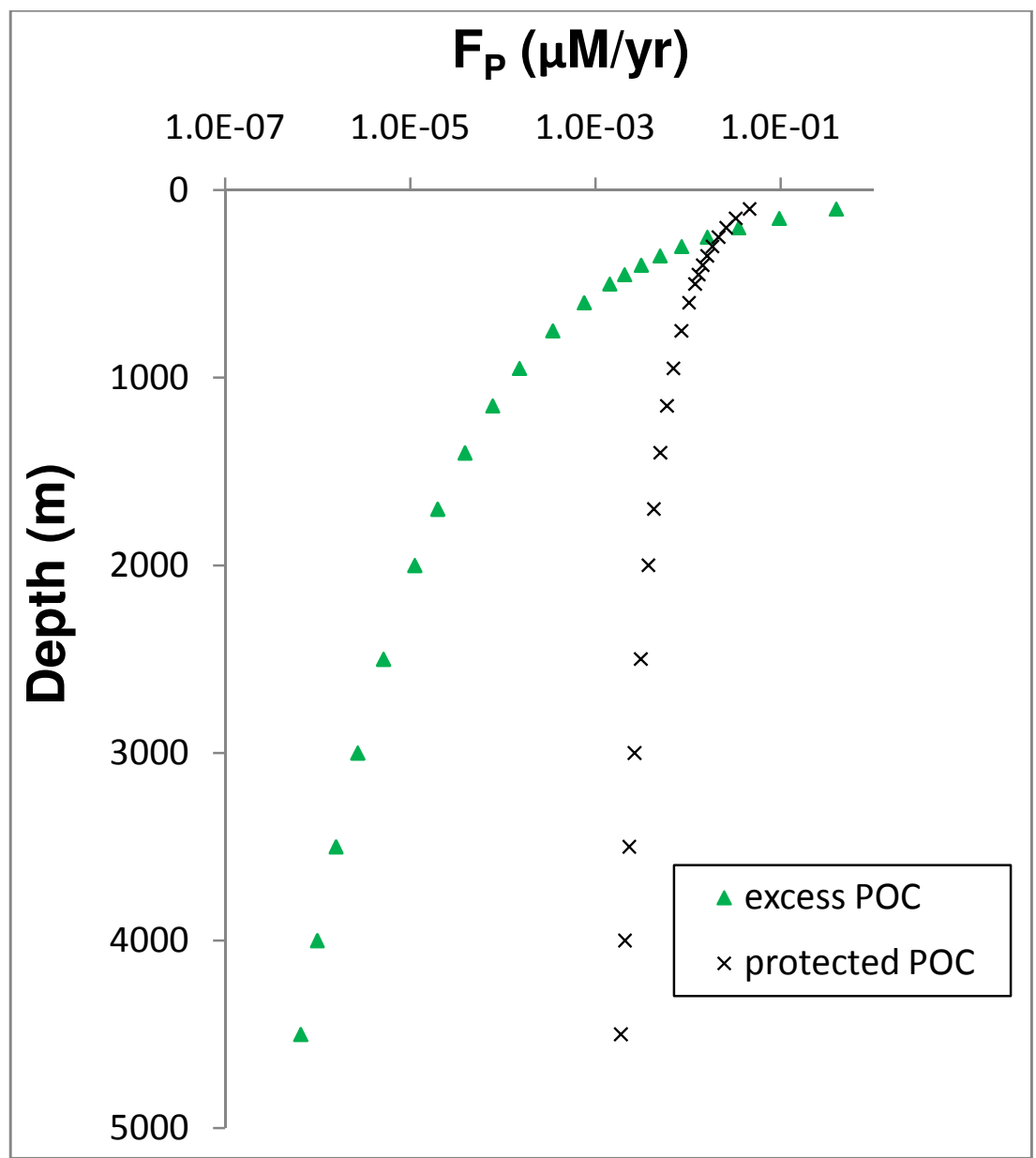

Figure 4e 


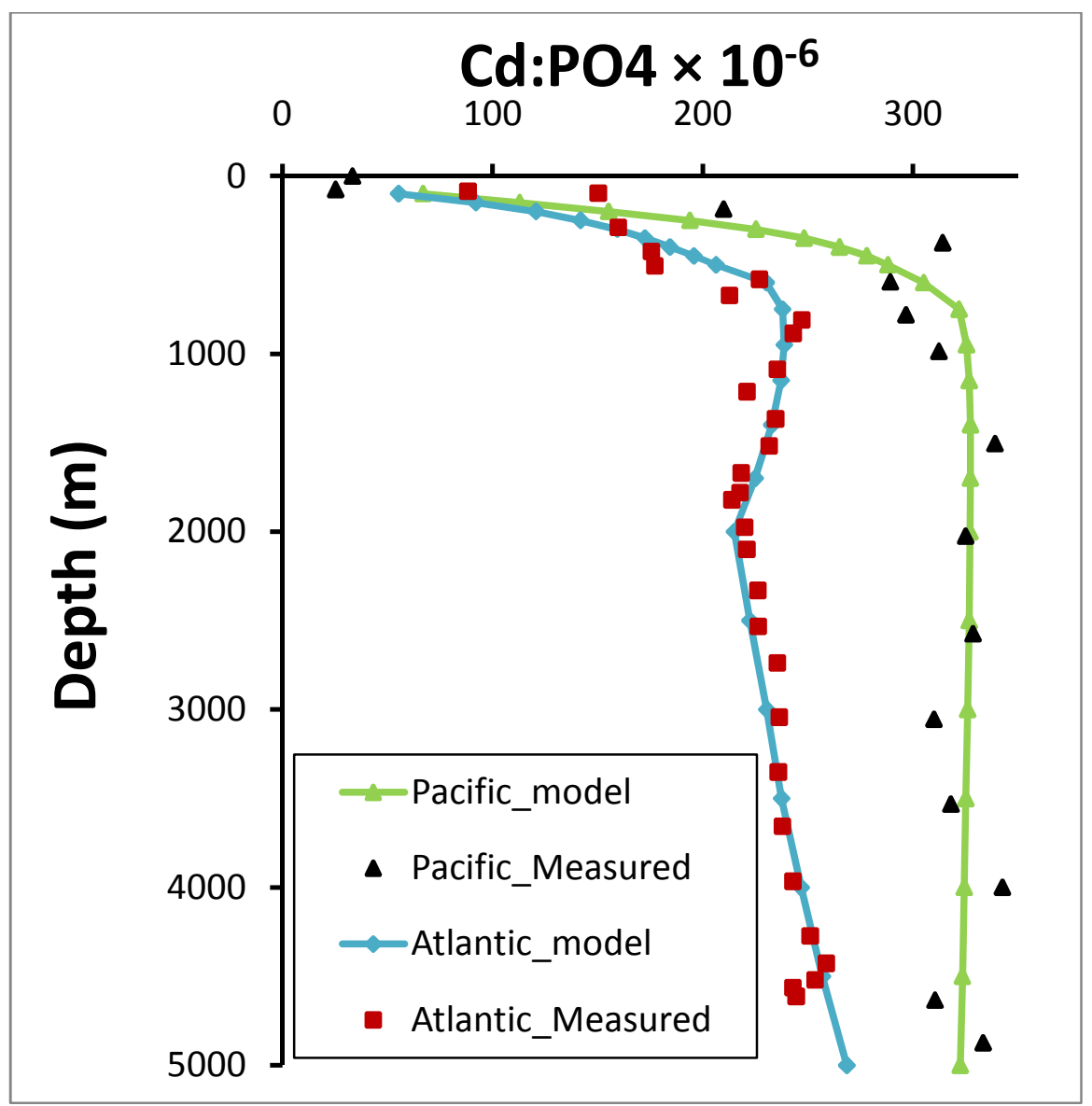

Figure 4f 


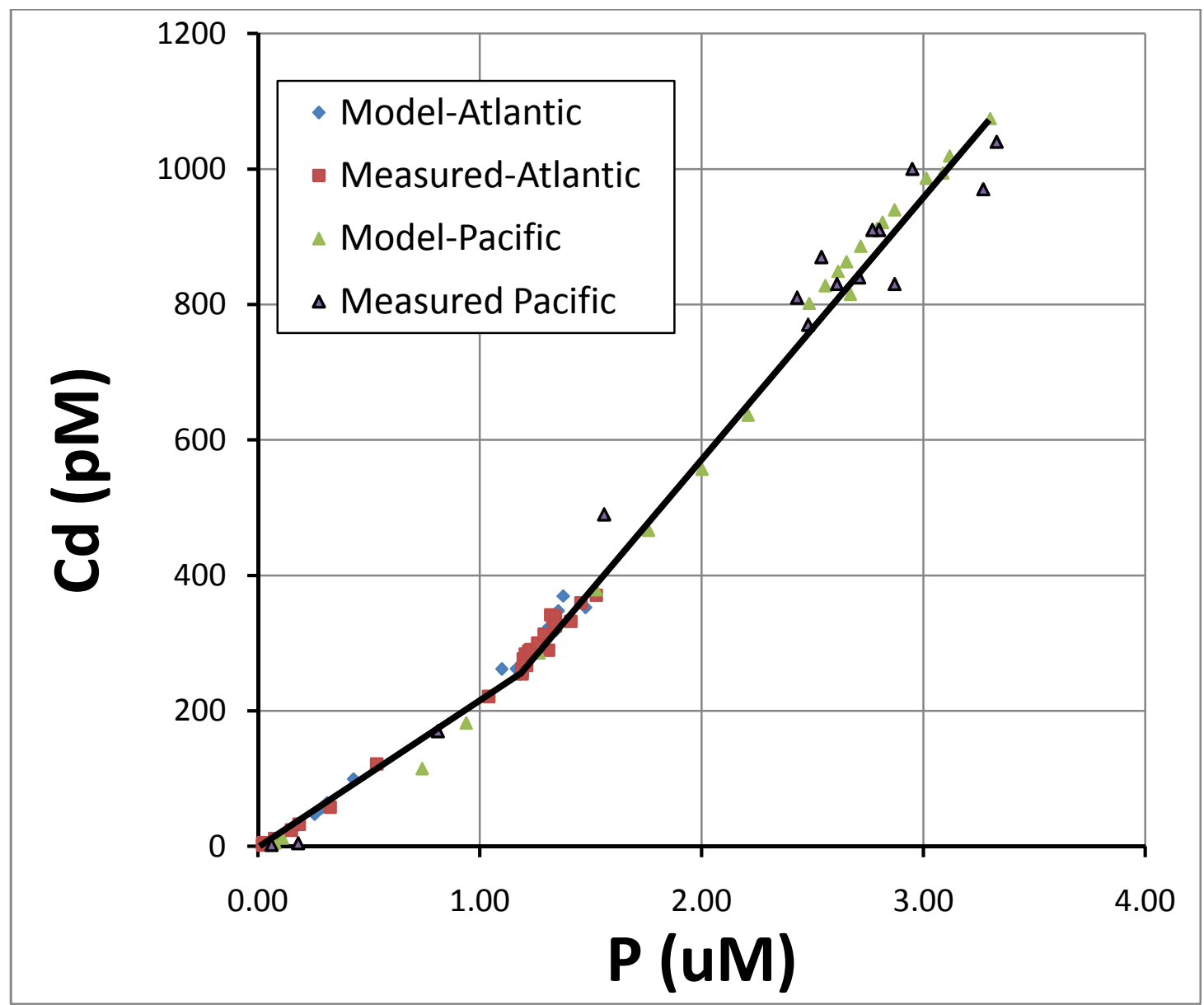

Figure 5 